\title{
SELEÇÃO PARA TAMANHO DO EMBRIÃO RELACIONADA COM O TEOR DE ÓLEO DO GRÃO DE MILHO ( $\mathscr{Z}_{\text {ea }}$ mays $\mathrm{L}$.)
}

\author{
LUIZ ALBERTO ROCHA BATISTA \\ Engenheiro Agrônomo \\ Empresa Brasileira de Pesquisa Agropecuárla
}

Orientador: GERALDO ANTONIO TOSELLO

\begin{abstract}
Dissertação apresentada à Escola Superior de Agricultura "Luiz de Queiroz", da Universidade de São Paulo, para obtenção do título de Mestre em Genética e Melhoramento de Plantas.
\end{abstract}

PIR A C ICABA

Estado de São Paulo - Brasil

Março - 1980 
A minha esposa

DEDICO

Aos meus pais, irmãos e sobrinhos OFEREÇO 
LUIZ ALBERTO ROCHA BATISTA, filho de Jocelino Batista da Silva e Rosa Rocha Batista, nasceu em Araçatuba, Estado de São Paulo,aos 14 dias do mês de agosto de 1951. Iniciou e completou seus estudos básicos em Araçatuba, SP.. Graduou-se em Engenharia Agronōmica, em dezembro de 1974, pela Faculdade de Ciências Agrárias e Veterināria, da Universidade Estadual Paulista "Jülio de Mesquita Filho" - UNESP, "Campus" de Jaboticabal, em Jaboticabal, SP.. Em 1975 ingressou na Empresa Brasileira de Pesquisa Agropecuāria (EMBRAPA), desenvolvendo atividade de pesquisa em milho e sorgo no Centro de Pesquisa Agropecuāria dos Cerrados (CPAC), em Planaltina, DF.. Em março de 1978, iniciou o curso de Mestrado em Genética e Melhoramento de Plantas, na Escola Superior de Agricultura "Luiz de Queiroz", da Universidade de São Paulo, em Piracicaba, SP.. 


\section{AGRADECIMENTOS}

Expressamos os nossos agradecimentos a todos aqueles que contribuiram para a realização deste trabalho e, de maneira especial, às seguintes pessoas e instituições:

Professor Dr. GERALDO ANTONIO TOSELLO, pela orientação e amizade.

Professor Dr. ERNESTO PATERNIANI, Diretor do Instituto e Chefe do Departamento de Genëtica da Escola Superior de Agricultura "Luiz de Queiroz" - USP, pelas sugestões e crïticas oferecidas na elaboração deste trabalho.

Aos colegas HELIO WILSON LEMOS DE CARVALHO e LAZARO JOSE CHAVES, pelas inümeras sugestões sobre vārios aspectos do trabalho.

Aos colegas HIROSHI (SANDRA) NODA, pela revisão do texto.

Aos colegas do Curso de Pōs-Graduação, pelo companheirismo.

Ao Departamento de Genética da Escola Superior de Agricultura "Luiz de Queiroz" - USP, nas pessoas de seus PROFESSORES e FUNCIONARIOS, pelos ensinamentos, facilidades concedidas e amizade.

EMPRESA BRASILEIRA DE PESQUISA AGROPECUARIA (EMBRAPA), pela oportunidade de treinamento a nỉvel de pōs-graduação. 
INDICE

Pāgina

LISTA DE TABELAS

LISTA DE FIGURAS

. RESUMO $\ldots \ldots \ldots \ldots \ldots \ldots \ldots \ldots \ldots \ldots \ldots \ldots \ldots \ldots \ldots \ldots$

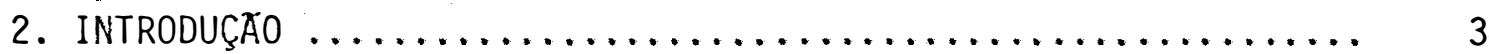

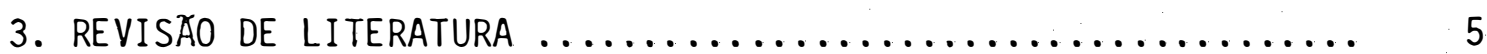

3.1. Herança do conteúdo de ōleo em milho ............... 5

3.2. Fatores que afetam o conteūdo de ôleo em milho ........ 7

3.3. Seleção para aumento do conteúdo de ōleo em milho ..... 10

3.4. Conteúdo de óleo e produtividade de grãos $\ldots . \ldots \ldots \ldots . . .16$

3.5. Ressonāncia magnética nuclear (RMN) na determinação do teor de óleo em grãos de milho $\ldots . . \ldots \ldots . . . .18$

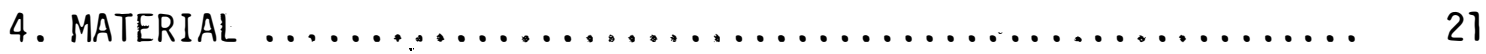

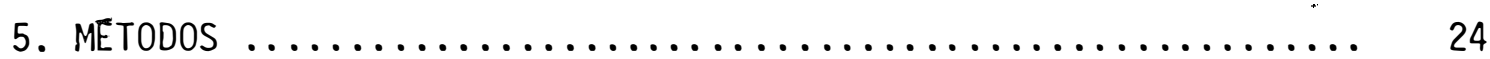

5.1. Obtenção da população Original $\ldots \ldots \ldots \ldots \ldots \ldots \ldots . . .24$

5.2. Obtenção da população Alto $01 e o \ldots \ldots \ldots \ldots \ldots \ldots \ldots . . \ldots 27$

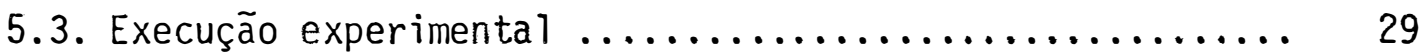

-5.4. Estimativas dos Parāmetros Estatísticos ............ 30

5.4.1. Anālise individual por população ........... 30

5.4.2. Anālise reunida por população para o 、 carāter porcentagem de ōleo ................. 35

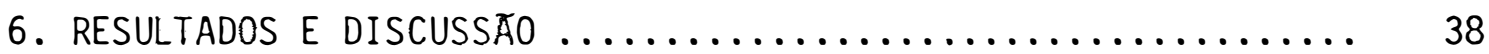

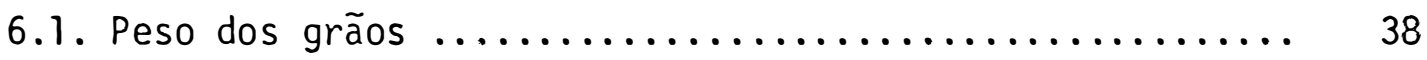

6.2. Volume dos grãos $\ldots \ldots \ldots \ldots \ldots \ldots \ldots \ldots \ldots \ldots . . . \ldots \ldots$ 
6.3. Densidade dos grãos $\ldots \ldots \ldots \ldots \ldots \ldots \ldots \ldots \ldots \ldots \ldots . . \ldots 1$

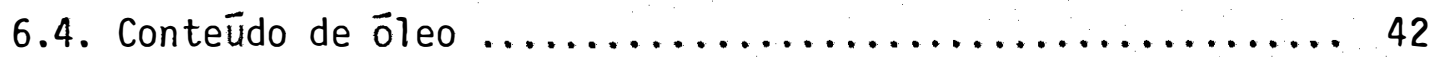

6.5. Estudos de correlação $\ldots \ldots \ldots \ldots \ldots \ldots \ldots \ldots \ldots \ldots \ldots \ldots$

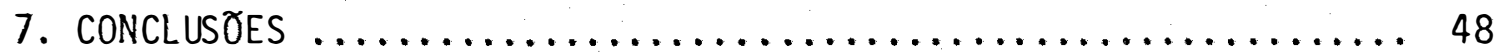

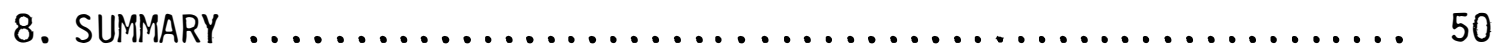

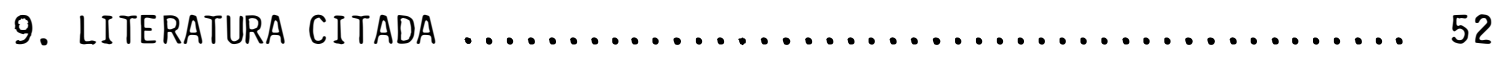

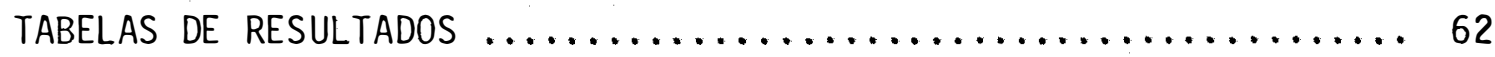

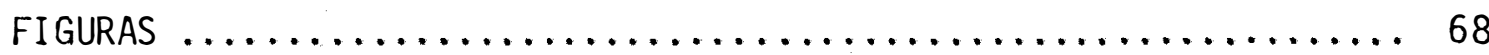




\section{LISTA DE TABELAS}

Tabela no

Pāgina

1 Anālise da variāncia para porcentagem de ōleo por população. Esperanças matemāticas dos quadrados médios (E(QM)) obtidas da anālise da variāncia considerando-se os efeitos de espigas como alea-

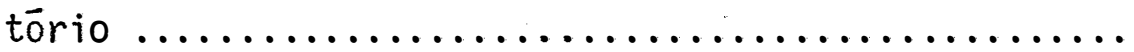

2 Modelo para cálculo do coeficiente de repetibilidade $(r$ ) para o carāter porcentagem de óleo dentro de cada população

3 Quadro da anālise da variāncia reunida por popula ção, para o carāter porcentagem de óleo. Considerando-se fixo o efeito de populações e aleatório os efeitos entre e dentro de espigas ............

4 Média $(\bar{x})$ e coeficiente de variação entre espigas ( $C . V_{\cdot_{E e}}$ ) para os caracteres de peso e volume de 100 grãos, densidade e porcentagem de óleo dos grãos de milho das populações Original e Alto $\widetilde{0}$ leo. Coeficiente de repetibilidade $(r)$ para 0 carāter porcentagem de ōleo nas populações estudadas

5 Progressos obtidos pela seleção dentro de famîlia de meios irmãos pará embrião grande nos caracteres de peso e volume de 100 grãos, densidade e

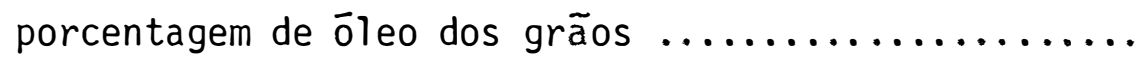


6 Anālise da variāncia para porcentagem de óleo, relativa as determinações realizadas entre e dentro de espigas $S_{1}$ da população Original $\ldots \ldots \ldots \ldots \ldots \ldots .64$

7 Anālise da variāncia para porcentagem de ōleo; relativa as determinações realizadas entre e dentro de espigas $S_{1}$ da população Alto 01 eo $\ldots \ldots \ldots \ldots \ldots \ldots$

8 Anālise da variāncia reunida por populações para porcentagem de óleo realizadas entre e dentro de espigas $S_{1}$ das populações Original e Alto 01 eo ........ 66

9 Coeficientes de correlação fenotîpica entre as mēdias dos caracteres: peso e volume de 100 grãos, densidade e porcentagem de ōleo dos grãos, nas

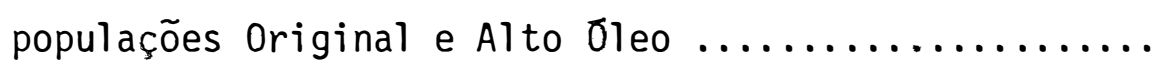




\section{LISTA DE FIGURAS}

Figura no

Pāgina

1 Distribuição das frequencias relativas ao peso de 100 grãos das sementes $S_{1}$ do Composto ESALQ-VD-2 ..... 69

2 Distribuição das frequências relativas ao volume de 100 grãos das sementes $S_{1}$ do Composto ESALQ-VD-2 ... 70

3 Distribuição das frequências relativas a Densidade das sementes $S_{1}$ do Composto ESALQ-VD-2 .......... 71

4 Distribuição das frequências relativas à porcenta-

gem de ōleo das sementes $S_{1}$ do Composto ESALQ-VD-2 ... 72 
1. RESUMO

Para a obtenção de genōtipos de milho com elevada produtividade em grãos e alto conteúdo de ōleo, realizou-se na população ESALQ-VD-2, seleção para produtividade entre famīlias de meios irmãos e seleção para embrião grande dentro das famîlias; uma vez que a porcentagem de óleo nos grãos apresenta estreita relação com o tamanho do embrião.

0 presente trabalho objetivou avaliar a eficiēncia do método de seleção empregado, atravēs da anālise do teor de ōleo encontrado apōs cinco ciclos de seleção. Além da porcentagem de ōleo, analisouse peso, volume e densidade dos grãos, utilizando-se sementes $S_{1}$ com a finalidade de evitar possiveis efeitos da fonte polinizadora.

Foram comparadas entre si a população Original, onde efetuou-se seleção entre e dentro de famîlias de meios irmãos para produtividade, e a população Alto రleo, onde, além da seleção entre famîlias para produtividade, efetuou-se tambēm, seleção dentro das famīlias para embrião grande. Avaliou-se noventa e seis espigas $S_{1}$ da população Original e quarenta e trēs da população Al to oleo. 
Os resultados obtidos permitiram concluir que o sistema seletivo usado para elevar o conteúdo de ōleo nos grãos de milho foi eficiente, promovendo um ganho médio por ciclo de $1,44 \%$ em relação a população Original. Os caracteres de peso, volume e densidade dos grãos mantiveram-se semelhantes aos da população Original. Embora, houvesse uma tendência de aumento no peso e volume e, redução na densidade dos grãos na população Alto రleo.

A população Alto Oleo, visualmente, sofreu efeitos maiores da variação ambiental nas características vegetativas, em relação à população Original. Não se obteve correlações significativas para os caracteres de peso, volume e densidade dos grãos em relação à porcentagem de ōleo em ambas populações estudadas. 
2. INTRODUÇÃO

Das inūmeras aplicações na alimentação humana, destacamos o milho como fonte de óleo, embora, sabendo-se que as variedades e hïbridos comerciais contēm normalmente cerca de 4 a $5 \%$ de ōleo em seus grãos. Nos ūltimos anos, o interesse pelo ōleo de milho tem aumentado grandemente em virtude das suas boas qualidades dietéticas, pois apresenta elevado teor de ácidos graxos insaturados, tais como os ácidos linoléico e oléico. Essa característica torna o ōleo especialmente recomendāvel para redução do nīvel de colesterol do sangue, com consequente prevenção de doen ças cardiovasculares. Atualmente, sua procura no mercado interno tem atingido nỉveis superiores à oferta, além do mercado internacional tanto pära o óleo, como para o grão com maior teor em óleo.

Para suprir essa demanda, uma possível, solução seria o meThoramento visando à obtenção: de genōtipos para maiorès teores de .óleo nos grãos. Contudo, a experimentação nos tem demonstrado que 0 aumento no teor de óleo provoca um decréscimo na produtividade, fator esse que tem sido responsāvel pela não utilização de germoplasmas comerciais com 
maiores teores de ōleo. Tem havido, entretanto, pesquisas sobre a possibilidade de se obter genōtipos para teores de óleo mais elevados, sem que a produtividade de grãos seja grandemente afetada.

0 presente trabalho tem como finalidade avaliar o método de seleção visual para embrião grande aplicado dentro das famỉlias de meios irmãos, selecionadas entre famîlias para produtividade, atravēs da anālise do conteūdo de óleo dos grãos obtidos de espigas autofecundadas de plantas das populações Original e Alto Oleo, ambas provenientes do com posto ESALQ-VD-2 de milho. As características de peso, volume e densidade dos grãos foram utilizadas para estudos de correlações e estudos comparativos entre as populações, afim de verificar as alterações que este tipo de seleção possa ter provocado na população Alto రleo. 


\section{REVISÃO DE LITERATURA}

\subsection{Herança do conteúdo de ōleo em milho}

Atravēs da anālise dos vārios constituintes do grão de miTho, HOPKINS et alii (1903) e LENG (1967) determinaram que cerca de 85\% do total de ōleo estão contidos no germe ou embrião. Correlações positivas entre o teor total de óleo e o tamanho do embrião ou mesmo entre o conteúdo de óleo no embrião, foram relatadas por BRUNSON et alii. SPRAGUE e BRIMHALL (1949), MILLER e BRIMHALL (1951) e RUSCHEL (1972). MILLER e BRIMHALL (1951) concluiram que o aumento no teor de óleo dos grãos de milho depende primeiramente do aumento da proporção do embrião em relação ao grão e da sua concentração de ōleo. 0 aumento do teor de óleo por sua maior concentração no embrião foram também relatadas por GLOVER e TOSELLO (1973).

Os estudos de: BEADLE et alii (1965) sòbre a composição do óleo determinaram que cerca de $86 \%$ dos ácidos graxos constituintes do óleo de milho comercial são os ácidos linoléico e oléico. 0 restante é representado pelos ācidos palmítico e esteárico, sendo somente $1 \%$ a contribuição dos ácidos linolēnico e araquinĩdico. Os conteúdos dos ácidos 
oléico e linoléico, foram mais extensivamente estudados por PONELEIT e ALEXANDER (1965), CURTIS et alii (1968), PONELEIT e BAUMAN (1970), JELLUM (1970), ROCHE et alii (1971) e WEBER e ALEXANDER (1975), que obtiveram correlações negativas entre esses ācidos graxos, chegando a indicar um controle monogènico, onde o baixo teor de ácido linoléico domina o alto teor e, o alto teor de ácido oléico domina o baixo teor.

0 estudo da herança do conteúdo de óleo em milho foi iniciado por SPRAGUE e BRIMHALL (1949) os quais evidenciaram que o baixo teor apresenta efeitos de domināncia sobre 0 alto teor de óleo nos grãos, sugerindo que tanto os efeitos gênicos aditivos como de domināncia estavam presentes, e que cerca de vinte pares de genes estão envolvidos, podendo afetar primeiramente o tamanho do embrião. Evidēncias de domināncia para o baixo teor em óleo foi também relatado por ELROUBY e PENNY (1967) e DUDLEY et alii. (1977).

LENG (1962a) e ELROUBY e PENNY (1967) indicaram a variāncia genética aditiva como o principal fator afetando o controle do conteúdo de óleo em milho. MORENO - GONZALEZ et alii (1975) usando as gerações $F_{2}$ e $F_{6}$ provenientes de cruzamentos entre variedades contrastantes de milho,para o conteúdo de ōleo, mostraram que a estimativa da variāncia genética aditiva foi cerca de oito vezes maior que a estimativa da va riāncia dominante em $F_{2}$, e cerca de quatro vezes maiòr em $F_{6}$. A estimativa da variāncia aditiva em $\mathrm{F}_{2}$ foi o dobro da estimada em $\mathrm{F}_{6}$; sugerindo que muitos loci de ação aditiva controlam o conteúdo de óleo em milho, estan do estes em ligação completa nos pais utilizados. A estimativa da variān cia dominante em $F_{6}$ não diferiu significativamente da estimada em $F_{2}$, 
indicando uma falta de efeito cie ligação sobre a variāncia dominante, a qual foi interpretada pelos autores como indicação de que os genes com ação dominante estão distribuidos por todo genoma em distāncias tais que possam ser herdados independentemente. Alguns genes são dominantes parà baixo teor de óleo e outros dominantes para alto conteūdo em óleo.

\subsection{Fatores que afetam o conteúdo de ōleo em milho}

Os efeitos relativos ao ambiente foram estudados por HOPKINS (1899), GENTER et alii (1956), JELLUM e MARION (1966), onde mostraram que as condições ambientais provocam grandes variações no conteúdo de óleo em milho, afetando grandemente o tamanho relativo do germe. As variedades de milho com maiores teores em óleo estão sujeitas a maiores interações ambientais.

JELLUM e MARION (1966) não observaram efeito quantitativo de ō e em relação as diferentes espigas provenientes de uma mesma planta.

LAMBERT et alii (1967) determinaram o efeito da posição do grão dentro de uma mesma espiga, para o conteúdo de óleo em milho. Tomando-se como base a porcentagem de óleo dos grãos analisados individualmente, os autores obtiveram que, em média, os grãos da parte central da espiga apresentam maior porcentagem de ōleo $(5,3 \%)$ do que os grãos da base $(5,0 \%)$ e os do àpice da espigá $(4,7 \%)$. Porém, quando foi utilizado o con teúdo total de óleo dentro do grão, usando a porcentagem de óleo e o peso dos grãos; os da parte basal, devido ao seu maior peso, apresentaram uma maior quantidade de óleo $(17,0 \mathrm{mg})$ que os da parte central $(14,0 \mathrm{mg})$ e os do 
āpice $(13,0 \mathrm{mg})$ das espigas dos hỉbridos analisados. 0 efeito da posição da semente na espiga de milho sobre a qualidade do óleo foi determinado por JELLUM (1967). A posição da semente na espiga apresentou maior influência nos ácidos oléico e linoléico, que no palmítico. De modo geral, a proporção do palmîtico e linoléico aumentam e a proporção do oléico diminuem linearmente com amostras provenientes da base para 0 ápice das espigas.

0 conteúdo de ōleo no milho è também influenciado pelo genótipo maternal. WOODWORTH e MUMM (1936, apud MILLER e BRIMHALL, 1951) observaram uma influência preponderante da fonte maternal sobre a porcentagem de óleo no grão de milho. Efeito este, determinado também nos trabalhos de MILLER e BRIMHALL (1951), CURTIS et alii (1956) e GARWOOD et alii (1970). MILLER e BRIMHALL (1951) determinaram a influência relativa do efeito maternal sobre o conteúdo de ōleo, utilizando cruzamentos em uma espiga por uma mistura de pólen proveniente de duas diferentes fontes. Os grãos produzidos foram identificados pela coloração do endosperma, pois as fontes polinizadoras diferenciavam quanto a esta característica. GARWOOD et alii (1970) observaram efeitos maternais sobre o conteū do de ōleo, em todas comparações realizadas em sementes $F_{1}$ provenientes de cruzamentos reciprocos. 0 efeito maternal foi determinado também para a porcentagem de óleo no germe e na proporção do germe em relação ao grão inteiro. Os resultados obtidos permitiram concluir que a combinação destes fatores, porcentagem de ōleo no embrião e proporção do embrião em relação ao grão, são as causas do efeito maternal, sobre a porcentagem de óleo. As diferenças no conteūdo de ōleo em cruzamentos recīprocos foram 
também relatadas por PONELEIT e BAUMAN (1970), os quais referem que estas diferenças, que foram variāveis entre as linhagens de milho testadas, são devidas principalmente ao efeito maternal. A respeito da variação do efeito maternal, em rélação ao genótipo, ROCHE et alii (1971) mostraram a existência de elevado efeito maternal nos grãos $F_{\gamma}$ de cruzamentos recípro cos entre os genótipos C 103 e R 84. Porém, este efeito não foi detectado nos cruzamentos envolvendo os genōtipos IHO (Illinois High 0il) com R 84 e C 103 com IHO.

GARWOOD et alii (1970) e RUSKOVA (1974) relataram efeitos citoplasmáticos sobre a porcentagem de ōleo em alguns cruzamentos. Contudo, todos os efeitos citoplasmáticos observados foram pequenos, quando comparados com o efeito fisiológico maternal. GARWOOD et alii (1970) determinaram como sendo de $0,14 \%$ o efeito citoplasmáticos em sementes $F_{1}$, provenientes de cruzamentos reciprocos entre variedades IHO de milho.

MILLER e BRIMHALL (1951), CURTIS et a7ii (1956), ALEXANDER e LAMBERT (1968), GARWOOD et alii (1970), PONELEIT e BAUMAN (1970), RUSCHEL (1972) e RUSKOVA (1974), relataram em seus trabalhos uma pequena, porém consistente influência exercida pelo grão de pólen, sendo este efeito similar ao de metaxenia. 0 termo metaxenia é definido em ALLARD (1971) como sendo a influência do pólen sobre tecidos maternal do fruto.

ALEXANDER e LAMBERT (1968) analisaram sementes $F_{1}$ de cruzamentos envolvendo as variedades IHO e ILO (Illinois Low 0il), com relação a produção de óleo e matéria seca, usando para tal comparação o conteúdo de calorias produzidas. 0 teor de óleo, de proteina e de 
carboidratos foram multiplicados pelos respectivos fatores: 9,$4 ; 5,4$ e 4,2 Cal/g, segundo WESTON e TODD (1963, apud. ALEXANDER e LAMBERT, 1968). Desta forma, a soma destes valores individuais, possibilita a obtenção da quantidade de calorias produzidas nos grãos de cada cruzamento analisado. Estes autores concluiram que os hỉbridos polinizados por pōlen provenien tes de plantas com baixo teor de ōleo (ILO), produziram significativamente baixas całorias em ōleo quando comparados com hỉbridos polinizados por pólen provenientes de plantas com alto teor de óleo (IHO). Contudo, em geral, a capacidade físiológica das płantas em armazenar energia (total de calorias por planta) não foi afetada pois ocorreu um aumento na quantidade de calorias nas fontes de proteina e carboidratos, quando a quantidade de calorias do óleo era reduzida peła fonte polinizadora.

\subsection{Seleção para aumento do conteūdo de ōleo em milho}

0 teor de ōleo nos grãos de mi Tho è passivel de aumentos pelo melhoramento genético e, vārios métodos de seleção foram estudados. 0 primeiro trabalho objetivando esta élevação do conteúdo de ōleo em miTho foi realizado por C.G.Hopkins, iniciado em 1896, em Illinois - USA (HOPKINS, 1899). Hopkins idealizou o método espiga-por-fileira, o qual consiste essencialmente na escolha de um grupo de espigas com caracteres desejāveis, sendo as sementes dessas espigas plantadàs em fileiras individuais. Deste modo obtem-se uma avaliação das progēnies das espigas escolhidas. As sementes remanescentes das melhores espigas nos testes de progēnie, são misturadas para obtenção da geração seguinte. 
0 método foi aplicado primeiramente na seleção para alto e baixo teor de óleo, e para alto e baixo teor de proteina nos grãos de miTho. Esses trabalhos continuam sendo conduzidos, constituindo assim o único exemplo, em plantas, de seleção para um carater quantitativo conduzido por mais de setenta gerações, com dados bem relatados. Os resultados obtidos com a seleção para ōleo serão examinados aqui com mais detalhes.

Como material original foram analisadas 163 espigas da variedade Burr White, dando uma média de $4,7 \%$ de óleo. As 40 espigas mais ricas em óleo foram escolhidas para iniciar a seleção para alto teor. Do mesmo modo, escolheram-se as 40 com menos ōleo para iniciar a seleção para baixo teor. Cada espiga foi plantada numa fileira, obtendo-se assim, uma progēnie. Os lotes, para arto e baixo teor, eram plantados cada um em lotes isolados de outros milhos. Na colheita colhiam-se espigas das fileiras com melhor aspecto agronōmico. As espigas eram então individual mente analisadas, escolhendo as dez fileiras mais ricas em ōleo e de cada uma destas eram tomadas quatro espigas. Obtinha-se assim um novo grupo de 40 espigas para repetir o plantio no próximo ano. Processo jdêntico era usado para seleção para baixo teor. Algumas modificações têm sido in troduzidas, mantendo-se entretanto o esquema básico de espiga-por-fileira.

Resultados de 50 gerações de seleção nestes materiais, foram relatados por WOODWORTH et alii (1952) salientando que a seleção para alto teor produziu aumentos regulares chegando a cerca de $15 \%$. A seleção para baixo teor chegou a $1 \%$ de ōleo nos grãos, sendo de se notar 
que depois de 25 a 30 gerações não se conseguiu diminuir substancialmente o teor de óleo. Isso certamente deve-se ao fato de que o teor de óleo es tá muito relacionado com o tamanho do embrião, tendo o material de baixo teor embriões muito pequenos, aparecendo inclusive, com certa frequência, sementes sem embrião. Seguramente há um limite fisiológico, abaixo do qual o embrião não é viāvel. Os progressos de seleção preditos atravēs da extrapolação da reta de regressão não foram de boa precisão, de acordo com LENG (1961). Os ganhos obtidos nas gerações avançadas tem sido concentrados em duas características morfológicas distintas: tamanho do embrião para seleção com alto teor e conteūdo de óleo no germe para baixo teor de óleo.

Muito embora a seleção tenha sido conduzida por muitas gerações, os dados indicam ainda a presença de razoável variabilidade em am bas as seleções. Com o fim de testar a variabilidade presente nesses miThos selecionados depois de quase 50 gerações, LENG (1962a e 1962b) iniciou no material de alto teor, uma seleção para baixo teor, e igualmente no material de baixo teor, uma seleção para alto teor, chamando essa seleção de reversa. ' Os resultados de vārios anos de seleção reversa conduziaram a progressos efetivos em ambas as direções consideradas, indicando desta maneira, que suficiente variabilidade genética estava presente nas duas amostras para permitir progresso por seleção.

A variabilidade genética nestes materiais foram tambēm detectadas por DUDLEY e LAMBERT (1969) apōs sessenta e cinco gerações. DUDLEY et alij (1974) relataram com detalhes todo o processo de seleção 
conduzida por setenta gerações. A porcentagem de óleo obtida nas progênies para alto teor foi em média, 16,6\%. Desta forma, este tipo de seleção proporcionou um ganho médio de $0,17 \%$ por ciclo. Estes resultados são de grande interesse porque indicam que, mesmo apōs muitas gerações de seleção, concentrando genes desejāveis, ainda persiste apreciāvel reserva gênica, o que leva a concluir que pelo menos para certos casos, essa reserva gênica é praticamente inesgotāvel.

Os métodos de melhoramento que fazem uso efetivo da variação genética aditiva foram propostos por PONELEIT e BAUMAN (1970), como sendo os methores para alteração do conteūdo de óleo em mi tho.

WEBER e ALEXANDER (1975) citam que a seleção massal tempro duzido variedades com teores de 0 leo variando de $0,4 \%$ a $17 \%$. ELROUBY e PENNY (1967) demonstraram que a seleção massal parece ser o método mais eficiente para elevar a porcentagem de ōleo nos grãos, porēm, a seleção recorrente para capacidade geral de combinação mostrou ser um método mais eficiente para produção de ōleo. Procurando obter dados comparativos entre dois sistemas de seleção para o aumento no conteúdo de ōleo nos grãos de mitho, SPRAGUE e BRIMHALL (1950) relataram sucesso marcadamente superior da seleção recorrente, em confronto com o sistema de selecionar em linhagens autofecundadas. 0 material original apresentava $7,2 \%$ de óleo e a média das linhagens autofecundadas na geração $S_{5}$ foi de $7,5 \%$, sendo que as duas melhores linhagens tinham $10,6 \%$ e $10,8 \%$ de óleo nos seus grãos. No sistema de seleção recorrente, a média da população no segundo ciclo foi de $10,5 \%$, sendo que valores máximos de $13,5 \%$ foram obtidos. A eficiēncia da seleção recorrente foi estimada como sendo de 2,6 vezes 
superior ao processo de autofecundação. Devemos ressaltar que esta estimativa foi subestimada, uma vez que o material de seleção recorrente continha ainda apreciāvel variabilidade genética para permitir progressos pos teriores, o que não acontecia nas linhagens autofecundadas. SPRAGUE et alii (1952) apresentaram dados adicionais comprovando a eficiēncia da seleção recorrente para aumento do teor de óleo usando outros germoplasmas.

ALEXANDER et alii (1970) usaram o sistema alternado de autofecundação e de polinização aberta para seleção de óleo em dois sintēticos de milho. Obtiveram aumentos de 4,5 a $10,2 \%$ para um dos materiais e de 4,8 a $8,8 \%$ no outro sintético. Com o uso da seleção recorrente reciproca, nestes dois materiais estes autores relatam um aumento no conteú do de óleo de 4,8 a $10,1 \%$ na variedade sintética Alexo e 5,5 a 8,7\% na va riedade sintética DO, após seis e oito ciclos de seleção, respectivamente.

RUSCHEL (1972) usando trēs métodos de seleção (progēnies autofecundadas, irmãos germanos è meios irmãos) em populações opaco-2 sin tético $A$, concluiu que os trēs métodos foram eficientes para o aumento na porcentagem de ōleo, obtendo em média um ganho de $0,37 \%$ sobre duas gerações. MIRANDA et alii (1976) avaliaram o sistema de famîlias de meios ir mãos na variedade Centralmex de milho, para produção de grão e ōleo. 0 mé todo de seleção simultānea entre e dentro de famîlias, de meios irmãos demonstrou ser eficiente no melhoramento para produtividàde de grão e de óleo em milho.

CURTIS et alii (1968), analisando sessenta e cinco gerações para aumento no conteūdo de óleo determinaram que a seleção para 
al to teor em ōleo aumentou o tamanho do germe. Isto è causado tanto pelo aumento na taxa de crescimento do germe como pelo seu maior peso final, e que a seleção para baixo teor atua no sentido contrārio, ou seja, diminue o tamanho do embrião. RUSCHEL (1972) indicou com base nas correlações encontradas, que a seleção para alto teor de óleo estā associada commaior embrião. RUSCHEL (1975) concluiu que o peso do embrião e a porcentagem deste com $\Theta$ teor de ōleo da semente permite prever um aumento no tamanho absoluto do embrião em resultados de seleção para elevar o teor de ōleo do grão de milho. PATERNIANI (1972) mostrou que a seleção visual dos grãos para o tamanho do embrião estā correlacionada com o teor de ōleo: A primeira geração de seleção para aumento do conteūdo de ōleo no milho, ba seado no tamanho do embrião foi satisfatōria. Este tipo de seleção, por ser bastante simples, poderā possibilitar um progresso razoável pelo menos nas primeiras etapas de um programa pała aumentar o conteúdo de óleo em milho.

KINOSHITA e PATERNIANI (1974a e 1974b) utilizando o sistemá de seleção entre e dentro de famîlias de meios irmãos, onde a seleção dentro das famîlias foi baseada no tamanho do germe, obtiveram um progres so esperado na ordem de $15 \%$ para o primeiro ciclo de seleção. Contudo, não se observou aumento no teor de óleo, concluindo que para se conseguir progressos quanto ao teor de ōleo, utilizando seleção para embrião grande é necessārio que o trabalhó seja acompanhado de anālises de laboratōrio para a determinação do teor de óleo das progēnies. 


\subsection{Conteúdo de ōleo e produtividade de grãos.}

Devido ao balanço fisiológico energético da planta, o aumento no conteúdo de óleo nos grãos de milho pode vir a provocar uma redução na quantidade de carboidrato e dando como consequência redução na produtividade de grãos. Isto é devido a relação calorífica entre o ōleo e carboidrato ser de $9,4: 4,2 \mathrm{Cal} / \mathrm{g}$, respectivamente (WESTON e TODD, 1963 apud ALEXANDER e LAMBERT, 1968). Desta forma, vārios autores tem demonstrado a redução da produtividade do milho quando se eleva 0 teor de óleo de seus grãos. WOODWORTH et ali i. (1952) analisando a produtividade de grãos na população com cinquenta gerações para alto ōleo, relataram que esta possue produtividacie média, aproximadamente $50 \%$ inferior aos hïbridos locais. ALEXANDER (1962, apud ELROUBY e PENNY, 1967) tratandose da possibilidade de se obter alta produtividade de grãos e alto conteū do em óleo, considerou, em bases fisiológicas, que o aumento de $1 \%$ no con teūdo de óleo nos grãos de mi tho deve provocar uma redução aproximada, na produtividade de grãos, de $75 \mathrm{Kg} / \mathrm{ha}$, desde que se considere constante a quantidade de calorias produzidas.

ALEXANDER et ali i (1970) comentam o programa de obtenção de hỉbridos para alto conteúdo de ōleo desenvolvido na década de trinta por Woodworth e Jugenheimer, em Illinois - USA. Os autores usaram o sistema de autofecundação, topcróss e retrocruzamento, juntamente com seleções para al to conteúdo de ōleo na variedade Illinois High 0il (IHO) de milho. Obtiveram linhagens com conteūdo de 50 a $75 \%$ superior às variedades originais. Contudo, os hỉbridos obtidos apresentaram baixa produtivi 
dade de grãos. Esta correlação negativa entre a produtividade de grãos e o conteúdo de óleo nos grãos foi a razão principal do insucesso de tal programa. DUDLEY et alii (1977) estudando os possīveis cruzamentos entre as variedades IHO (IIlinois Hig 0il), ILO (Illinois Low 0il), RHO (Reverse High 0il) e RLO (Reverse Low 0il), encontraram correlações negativas entre a produtividade de grãos e a porcentagem de óleo nos grãos.

Contrastando com os autores que determinaram que a elevação do conteúdo de óleo nos grãos afeta negativamente a produtividade de grãos, MILLER e BRIMHALL (1951) verificando a relação entre o conteúdo de ōleo e a produtividade de grãos, encontraram uma correlação estatisticamen te significativa ao nível de $5 \%$ de probabilidade e positiva $(r=0,27)$ entre esses caracteres, onde a produtividade variou de 2.300 a $5.000 \mathrm{Kg} / \mathrm{ha}$ e o conteúdo de ōleo de 2,8 a 5,04\%. Num segundo ensaio esses mesmos autores usaram 118 linhagens de milho branco ceroso, isolados de uma popula ção segregante provenientes de cruzamentos entre IHO e a linhagem cerosa 0S-420 e uma dessas linhagens foi autofecundada e retrocruzada para o hîbrido ceroso $\mathrm{K} 55 \times \mathrm{K} 67$. A produtividade das progênies obtidas do retrocruzamento variou de 3.400 a $5.700 \mathrm{Kg} / \mathrm{ha}$, e o seu conteúdo de óleo variou de 5,2 a $8,0 \%$, obtendo uma correlação positiva para essas duas variáveis de $r=0,41$. Concluindo que um aumento de $3 \%$ no conteúdo de óleo pode ser obtido sem afetar a produtịividade do material.

ALEXANDER et alii (1970) através de alguns dados empíricos sugeriram que hỉbridos com 7 a $8 \%$ de óleo apresentam características agro nōmicas semelhantes aos hỉbridos comerciais. Os estudos realizados por 
PATERNIANI (1972) sobre a relação entre o tamanho do embrião e o teōr de oleo em milho, indicaram ser possivel elevar o teor de óleo sem reduzir a produtividade de grãos.

\subsection{Ressonāncia magnētica nuclear (RMN) na determinação do teor de óleo em grãos de milho.}

A ressonāncia magnētica nuclear ē um fenōmeno que pode ser observado em nūcleos que possuem momento magnētico nuclear $(\vec{\mu})$ diferente de zero. Tal fenōmeno é devido à absorção de energia pelo núcleo, energia esta fornecida por uma fonte externa, e que no caso da RMN estā na faixa de rádio frequēncia (R.F.) (BISCEGLI, 1977). 0 óleo nas sementes se encontram em estado líquido, micro-encapsulado dentro das paredes celulares das sementes. Pequena reação ocorre entre a parede celular e o ōleo. Desta forma, estando no estado líquido, a energia absorvida estimula-o, provocando uma estreita linha de ressonāncia. A parede celular e o resto da semente não contribuem para esta restrita banda de ressonância, e desta forma o tamanho deste componente è proporcional somente ao conteúdo de ōleo das sementes (N.I.L., 1972).

A determinação do conteūdo de ōleo pelo uso da ressonāncia magnética nuclear, diferencia do método quĩmico usual pelo fato de que esta medida é realizada na prōpria semente, livre dos erros de extração por solventes. Além de poder determinar o conteūdo de óleo de uma única semente, não a inviabiliza, pois trata-se de um método não destrutivo. Esta é uma grande vantagem para os programas de melhoramento, pois 
pussibilita a obtenção da progênie da prōpria semente analisada, obtendo desta forma maiores progressos dentro do processo seletivo.

A relação entre os métodos de extração por solvente e o uso da RMN na determinação do conteúdo de óleo em sementes de milho, foi estudado por CONWAY e EARLE (1963) onde obtiveram entre estes métodos, uma correlação de $r=0,993$. Desta forma os dados obtidos por ambos métodos são quase que idēnticos. Importantes observações sobre o uso da anālise do conteúdo de óleo das sementes de milho pelo método RMN foi dada por ALEXANDER et ali i (1967) onde citaram que as amostras devem ter pe sos semelhantes, com um mesmo teor de umidade e a mesma variação no teor de ōleo, ou seja, as sementes devem provir de uma mesma posição da espiga de preferência da parte central.

BAUMAN et alii (1963 e 1965) utilizaram o método RMN para determinar o conteūdo de óleo das sementes $F_{2}$ e $F_{3}$ provenientes do cru zamento entre os genōtipos $\mathrm{Hy} \times 0 \mathrm{~h} 45$ e suas respectivas progēnies. $\mathrm{Na}$ determinação da herança da semente com sua progēnie usou a anālise de sementes individuais. Correlação do conteūdo de óleo nas sementes $F_{2}$ e suas progēnies foi altamente significativa com $r=0,75$. Entre seis famîlias $F_{3}$ e suas respectivas progēnies as correlações foram todas altamen te significativas com $r$ variando de 0,54 a 0,85. Apesar da grande diferença no conteúdo de ōleo entre sementes de uma mesma espiga, estas foram herdāveis na geração $F_{2}$ e tambēm na geração $F_{3}$, onde a heterozigose ē con sideravelmente reduzida. A variabilidade no conteúdo de óleo entre semen tes $F_{3}$ dentro da famîlia foi correlacionado com grande variabilidade em 
suas progēnies. Oito sementes $F_{2}$ com maior conteúdo de ōleo produziram progēnies com média de $4,99 \%$. Comparando com a média de todas as progê nies $(4,28 \%)$, isto representa um ganho de $16 \%(0,71 \%$ de ōleo), atravēs de seleção de uma única semente em uma geração. A seleção de uma única semente para o conteūdo de óleo promove uma boa pressão de seleção, podendo vir a ser usado conjuntamente com outros métodos de melhoramento para aumentar a eficiēncia na seleção para alto conteúdo de óleo em miTho. 
4. MATERIAL

A população básica utilizada no presente trabalho foi a ESALQ-VD-2, sintetizada no Departamento de Genética da Escola Superior de Agricultura "Luiz de Queiroz" (ESALQ-USP), a partir de populações de milho da raça Tuxpeño obtidos do CIMMYT, além de populações desenvolvidas em programas locais (PATERNIANI, 1968 e PATERNIANI et alii, 1977).

Uma descrição sucinta, quanto às caracterīsticas destas po pulações, è dada por LIMA (1977) que assim expõe:

$\mathrm{WP}_{2}$ : Grãos amarelos, dentados. Formada a partir de amostras coletadas no norte de Vera Cruz, México: Ver Gpo 48, Ver 168 e SLP 15.

$W_{6}$ : Grãos brancos do tipo dentado e semi-dentado, formada a partir de uma mistura de sementes obtidas dos melhores cruzamentos intervarietais de Tuxpeño $x$ Etó Blanco.

WP 9 : Grãos brancos do tipo meio-dente, formada a partir de uma mistura de sementes de diversas variedades de Tuxpeño de alta produtividade, como Mix e Colina Gpo, , cruzadas com Eto Blanco. 
WP ${ }_{10}:$ Grãos dentados amarelos, conhecida como Composto III Centro Americano. Formada a partir de millhos duros amarelos do Grupo Cubano (Cuba 40 e Hawai 5) e de milhos dentados Tuxpeño Amarelos (SLP-164).

$\mathrm{WP}_{27}$ : Grãos dentados brancos da raça Tuxpeño, cultivadas em Vera Cruz, Mé xico.

$\mathrm{WP}_{29}$ : Carmem - Grãos dentados de coloração branca pertencente ā raça Tuxpeño, origināria de Vera Cruz, Mexico.

$\mathrm{WP}_{32}$ : Mix 1 - Grãos dentados brancos da raça Tuxpeño, formada no programa de melhoramento da Costa Rica.

$W_{37}$ : Venezuela 3 - Milho dentado branco, obtido por seleção na Venezuela.

Piramex: Milho Tuxpeño sintético amarelo, obtida pelo programa de melhoramento de milho do Instituto de Genética da E.S.A."Luiz de Queiroz", Piracicaba, SP.

América Central: Variedade de mitho de grãos dentados amarelos de germoplasma predominantemente Tuxpeño, obtida pelo programa de melhoramento de milho do Instituto de Genética da E.S.A."Luiz de Queiroz", Piracicaba, SP.

Azteca: Representante da raça Tuxpeño amarelo, obtidà pela Seção de Cereais do Instituto Agronōmico do Estado, Campinas, SP.

Maia: Variedade sintētica com germoplasma de origem mexicana e criada pela Seção de Cereais do Instituto Agronōmico do Estado, Campinas, SP. 
0 programa de obtenção da população de milho ESALQ - VD - 2 iniciou-se em 1965, com o cruzamento entre plantas de amostras representativas das doze populações já citadas. 0 material resultante desses cru zamentos foi submetido a quatro gerações de recombinação em lote isolado de despendoamento, nos anos de 1966, 1967, 1968 e 1969. A população proveniente do campo de recombinação do ano de 1968 caracterizava-se por ser altamente heterogēnea, bem adaptada, de alta produtividade. A altura das plantas e a posição das espigas mostravam-se relativamente altas $\quad(2,81 \mathrm{~m}$ e $1,71 \mathrm{~m}$, respectivamente) e as espigas apresentavam 14 fileiras de grãos dentados brancos e amarelos (QUEIROZ, 1969). 
5. METODOS

\subsection{Obtenção da população Original.}

No ano de 1970 foi plantado um lote isolado da população ESALQ - VD - 2 Original, na qual foi aplicada seleção massal. As 700 espi"gas obtidas de plantas agronomicamente superiores foram selecionadas, debulhadas e as sementes mantidas separadamente, constituindo-se familias de meios irmãos. Esta população foi chamada ESALQ-VD-2 MI e a partir dela iniciou-se a seleção entre e dentro de famĩlias de meios irmãos.

0 método de seleção entre e dentro de famīlias de meios irmãos proposto por LONNQUIST (1964) e com algumas modificações, principalmente no que se refere ao emprego de semente remanescentes, foi conduzido como segue, segundo LIMA (1977).

As 700 famîliás de meios irmãos selecionadas no ano agrîcola de 1970/71 e correspondente à população ESALQ-VD-2 MI foram. testadas em sete grupos de 100 famîlias, empregando-se o delineamento látice $10 \times 10$ com trēs repetições para cada grupo. Cada parcela foi constituĩda 
de uma fileira de 5,0m de comprimento, no espaçamento de 1,0m entre fileiras e $0,40 \mathrm{~m}$ entre covas. Cacia cova recebeu três sementes, deixando apōs o desbaste duas plantas.

Apōs o completo desenvolvimento das plantas, foram feitas observações de interesse agronōmico, em duas das trēs repetições utilizadas, tais como: altura média das plantas, altura média da inserção da primeira espiga na planta e acamamento. A seguir foi feita a contagem do nümero de plantas por parcela (stand). Na colheita foram anotados o peso das espigas despalhadas e o teor de umidade dos grãos correspondentes a cada parcela experimental. As produções observadas no campo, correspondentes a cada parcela, foram corrigidas utilizando-se a seguinte fórmula:

$$
P C_{15,5 \%}=\frac{P C(1-U)}{0,845}
$$

onde:

$$
\begin{aligned}
& P_{15,5 \%} \text { : peso de campo corrigido para } 15,5 \% \text { de umidade; } \\
& P C \quad \text { : peso de campo observado; } \\
& \text { U : umidade observada em cada parcela. }
\end{aligned}
$$

A seguir foi feita correção para "stand", empregando-se a fórmula de ZUBER (1942):

$$
P C C=P C_{15,5 \%}^{:} \frac{T-0,3 F}{T-F}
$$

onde:

$$
\text { PCC : peso de campo corrigido para "stand" ideal; }
$$


$P C_{15,5 \%}$ : peso de campo corrigido para $15,5 \%$ de umidade;

T : número de plantas ideal por parcela;

F : número de plantas perdidas por parcela.

Este ajuste adiciona 0,7 da produção média para cada planta perdida e considera que 0,3 é recuperado pelas plantas vizinhas $\bar{a}$ faTha.

Apōs a obtenção dos dados finais, baseando-se no comportamento médio das famîlias nas trēs repetições quanto aos caracteres: produtividade, altura de plantas e espigas, acamamento e "stand", foram selecionadas cerca de 100 melhores famîlias de meios irmãos. As sementes remanescentes dessas familias selecionadas foram utilizadas no plantio em lote isolado de despendoamento no ano agrícola de 1972/73 com objetivo de proceder a recombinação das mesmas. De cada uma dessas familitias foram es colhidas de 4 a 5 plantas obtendo-se 500 famîlias de meios irmãos. Essa nova população foi chamada de ESALQ-VD-2 MI HSI. Essas 500 famīlias de meios irmãos foram avaliadas no ano agrícola de 1973/74, em cinco ensaios em látice $10 \times 10$ com três repetições em cada grupo. Após a condução dos 'ensaios e obtenção dos dados, como descrito anteriormente, as famîlias se lecionadas foram recombinadas no ano seguinte, permitindo a obtenção de 500 famỉlias correspondentes a população ESALQ-VD-2 MI HSII.

No ano agrícola $1975 / 76$ as 500 famîlias de meios irmãos fo ram avaliadas e as melhores famîlias recombinadas no ano agrícola seguinte, permitindo dispor de 500 novas famillias correspondentes ao ESALQ-VD-2 
MI HSIII que foi denominada, no presente trabalho de população Original.

\subsection{Obtenção da população Alto ర1eo}

Com objetivo de se ter uma variedade de milho com alto teor de óleo e de boa produtividade de grãos, destinada a atender às neces sidades das indústrias de ōleo de milho, iniciou-se seleção para alto teor em ōleo nos grãos do composto ESALQ-VD-2.

0 mētodo utilizado foi o de seleção entre e dentro de famỉlias de meios irmãos, da maneira descrita a seguir (PATERNIANI, 1979) 느.

Durante 0 ano agrỉcola de $1972 / 73,1000$ progēnies meios irmãos do compos to ESALQ-VD-2 MI foram testadas para produtividade e caracterīsticas agronōmicas em 10 ensaios látice $10 \times 10$ com 4 repetições ca da. As repetições 1,2 e 3 foram semeadas em outubro, com sementes normais. As parcelas compreenderam de uma fileira de $10,0 \mathrm{~m}$, semeando-se três sementes em cada cova espaçadas entre si de $0,40 \mathrm{~m}$. 0 espaçamento entre fileiras foi de 1,0m. Após o desbaste deixou-se duas plantas por cova. 0 "stand" completo teve 50 plantas por fileira. A repetição 4 , foi semea da em novembro, cerca de um mès mais tarde que as repetições 1,2 e 3 , em lote isolado de despendoamento. Essa repetição foi semeada com sementes selecionadas, visualmente, para embrião grande de cadà uma das progēnies de meios irmãos. Semeou-se na proporção de duas fileiras femininas, que foram despendoadas, para uma fileira masculina. As sementes usadas para - plantio das fileiras masculinas foram constituidas por uma mistura, em quantidades iguais, de sementes das 1000 progēnies de meios irmãos e a IT PATERNIANI (1979), comunicação pessoal. 
semeadura foi realizada em duas épocas, com intervalo de 7 a 8 dias. Essas sementes, tambēm, foram escolhidas para embrião grande.

Os tratos culturais foram as normais à cultura de milho. Pouco antes do florescimento, eliminou-se nas fileiras masculinas da quar ta repetição, as plantas inferiores e fora de tipo.

Apōs a colheita das repetições 1,2 e 3 identificou-se as progēnies mais produtivas. $\mathrm{Na} 4 \mathrm{a}$. repetição, colheu-se as 10 melhores plantas dentro das 200 progênies mais produtivas, de acordo com os resultados das três primeiras repetições. Na colheita deu-se preferēncia às plantas prolificas (mais de uma espiga por planta) ou espigas grandes e bem empałhadas, plantas erectas e com inserção de espigas não muito alta. Manteve-se sempre juntas as espigas de plantas prolíficas. Apōs a secagem das espigas, escolheu-se as 1000 espigas melhores, considerando as espigas de plantas prolificas como uma espiga. Debulhou-se cada espiga individualmente, constituindo a população ESALQ-VD-2 MI HSHOI (um ciclo de seleção entre famillias de meios irmãos para produtividade e dentro de famîlias para embrião grande).

0 mesmo procedimento foi realizado nos anos agrícolas de $1973 / 74 ; 1974 / 75 ; 1975 / 76$ e 1976/77. Obteve-se desta forma no final do ano agrícola de 1976/77 a população ESALQ-VD-2 MI HSH̉oV, ou seja, popula ção ESALQ-VD-2 MI com cinco ciclos de seleção entre famīlias de meios irmãos para produtividade e dentro de famîlias para embrião grande, denominada no presente trabalho de população Alto Oleo. 


\subsection{Execução experimental}

No ano agricola de 1978/79 uma amostra de sementes, tanto da população Original, como da Alto Oleo foram plantadas e as espigas das plantas autofecundadas, afim de se evitar possiveis efeitos de fonte polinizadora. Obtendo, desta forma, sementes $S_{1}$. Da população Original obteve-se 96 espigas $S_{1}$, enquanto que da população Alto oleo foram obtidas 43 espigas. Estas espigas apōs serem colhidas foram debuthadas individualmente e armazenadas em cāmara seca para a uniformização da umidade dos grãos, que ocorreu ao redor de $12 \%$.

Os dados obtidos das sementes $s_{1}$ foram os seguintes:

a) Peso de 100 grãos: sementes representativas da parte central de cada espiga foram selecionadas e obteve-se seu peso em gramas;

b) Volume de 100 grãos: utilizou-se o método da diferença de volume medido pelo deslocamento da coluna de etanol, em mililitros;

c) Densidade dos grãos: apōs a obtenção do peso e volume dos grãos, a relação entre estes caracteres forneceu a densidade, em gramas por mi lilitro;

d) Porcentagem de óleo: de cada espiga foram escolkidas duas amostras de quinze grãos cada uma, 'os quais após sua moagem procedeu a determi nação da porcentagem de öleo do modo descrito a seguir(TOSELLO, 1978) $\frac{1}{1}$ :

I' TOSELlo, 1978. Comunicação pessoat. 
cartuchos de papel de filtro, devidamente numerados, foram colocados a uma temperatura de $70^{\circ} \mathrm{C}$ durante 30 minutos para secagem, obtendo seus pesos secos $\left(P_{1}\right)$. As amostras do material moido foram colocadas nesses car tuchos, tomando-se o cuidado de não compactar o material, o qual foi seco até peso constante $\left(6\right.$ horas a $\left.70^{\circ} \mathrm{C}\right)$, após o qual foi pesado $\left(P_{2}\right)$. Depois de grampeados e secos novamente por uma hora à mesma temperatura, fo ram novamente pesados $\left(P_{3}\right)$. Procedeu-se, a seguir, a extração do ōleo das amostras usando n-hexano, durante 14 horas, em extrator de Soxhlet. Apōs este tempo as amostras foram secas durante 6 horas a uma temperatura de $70^{\circ} \mathrm{C}$ e determinado seu peso $\left(P_{4}\right)$. Através da diferença entre $P_{2}$ e $P_{1}$, obteve-se o peso seco da amostra antes da extração do óleo. Pela diferença entre $P_{3}$ e $P_{4}$, obteve-se a quantidade de óleo contida na amostra. A porcentagem de ōleo foi obtida utilizando-se a seguinte expressão:

$$
P 0=\left(\left(P_{3}-P_{4}\right) /\left(P_{1}-P_{2}\right)\right) \cdot 100
$$

onde:

PO : porcentagem de óleo na amostra analisada.

5.4. Estimativas dos Parāmetros Estatísticos

5.4.1. Anālise individual por população

Os dados de porcentagem de óleo obedećeram ao esquema do delineamento inteiramente casualizado. As espigas dentro de cada população foram consideradas como tratamentos, e as amostras dentro das espigas como nümero de determinações, segundo o modelo linear: 


$$
Y_{i k}=m+b_{i}+d_{k}(i)
$$

onde:

$$
\begin{aligned}
& Y_{i k}: \text { observação da espiga } \underline{i} \text { na determinação } \underline{k} ; \\
& m \quad: \text { média geral; } \\
& b \quad \text { : efeito do tratamento (espiga) } \underline{i} ; \\
& d_{k(i)}: \text { efeito da determinação } \underline{k} \text { dentro do tratamento } \underline{i}
\end{aligned}
$$

0 modelo visa a diferença de teor de óleo entre as espigas obtidas. 0 quadro do esquema da anālise da variância individual por população é apresentado na Tabela 1.

Tabela 1. Anālise da variāncia para porcentagem de óleo por população. Esperanças matemäticas dos quadrados médios (E(QM)) obtidas da anālise da variāncia considerando-se os efeitos de espigas como aleatório

\begin{tabular}{llllc}
\hline Fontes de Variação & G.L. & Q.M. & E(Q.M. & $F$ \\
\hline Entre espigas & $n-1$ & $Q_{1}$ & $\sigma_{d e}^{2}+d \tilde{\sigma}_{E e}^{2}$ & $Q_{1} / Q_{2}$ \\
Dentro de espigas & $n(r-1)$ & $Q_{2}$ & $\sigma_{\text {de }}^{2}$ & - \\
\hline Total & $n r-1$ & & & \\
\hline
\end{tabular}

onde:

$$
\begin{aligned}
& n \text { : nümero de espigas analisadas por pupulação; } \\
& d \text { : nümero de determinações dentro de cada espiga; } \\
& Q_{1} \text { : quadrado médio entre espigas; } \\
& Q_{2} \text { : quadrado médio dentro de espiga; }
\end{aligned}
$$


$\tilde{\sigma}_{\text {de }}^{2}$ : estimativa da esperança matemática da variāncia dentro de espigas $=Q_{2}$;

$\tilde{\sigma}_{E e}^{2}$ : estimativa da esperança matemätica da variāncia entre espigas $=\left(\left(Q_{1}-Q_{2}\right) / r\right)$.

Dos dados de porcentagem de ōleo obtiveram-se ainda os coeficientes de variação entre e dentro de espigas pelas expressões:

$$
C . V \cdot{ }_{E e}=\frac{\sqrt{\bar{\sigma}_{E e}^{2}}}{\bar{x}} \cdot 100
$$

e

$$
c . v \cdot \text { de }=\frac{\sqrt{\bar{\sigma}_{\text {de }}^{2}}}{\bar{x}} \cdot 100
$$

onde:

C.V.Ee : coeficiente de variação entre espigas;

C.V.de : coeficiente de variação dentro de espigas;

$\bar{x} \quad$ : estimativa da média geral para porcentagem de ôleo. .

Com relação aos dados de peso, volume e densidade dos grãos, pelo fato de se ter somente uma determinação por espiga, obtevese a média e o coeficiente de variação entre espigas.

Os dados obtidos das caracteristicas estudadas foram tomados em pares para determinação das correlações entre estas, para cada população, segundo a expressão:

$$
r_{x y}=\frac{\operatorname{Cov}_{x y}}{\bar{\sigma}_{x} \cdot \bar{\sigma}_{y}}
$$


onde:

$r_{x y}$ : coeficiente de correlação fenotîpica entre as características $x$ e $y$;

$\operatorname{Cov}_{x y}$ : covariāncia entre as características $x$ e y;

$\bar{\sigma}_{x}$ : estimativa do erro padrão associado a caracteristica $x$;

$\hat{\sigma}_{y}$ : estimativa do erro padrão associado a característica $y$.

A significāncia dos coeficientes de correlação foram avaliadas pelo teste " $t$ ", segundo a expressão (STEEL e TORRIE, 1960):

$$
t=\frac{r-\rho}{\sqrt{\frac{1-r^{2}}{n-2}}}
$$

onde:

$t$ : estimativa de " $t$ " para o contraste a ser testado;

$r-\rho$ : contraste a ser testado, para uma hipótese de nulidade onde consideramos $\rho=0$;

n-2: graus de liberdade pelos quais o contraste foi testado; onde $n$ vem a ser o número de pares em que foi obtido o valor do coeficiente de correlação $(r)$.

Do quadro de anālise para porcentagem de ōleo, obteve-se o coeficiente de repetibilidade para o carāter, em àmbas as populações. Este coeficiente de repetibilidade $(r)$ é utilizado para medir a capacida de que os individuos de uma população possuem em repetir a expressão do carāter analisado. Pelo fato da variabilidade entre as espigas de uma 
população conter, alēm da variação genética, tambēm parte da variação ambiental, este coeficiente corresponde ao limite máximo da herdabilida de do carāter. Este coeficiente foi calculado, nas duas populações, para o carāter porcentagem de óleo, segundo o esquema de anāi ise interpopulacional apresentado na Tabela 2 (VENCOVSKY, 1977).

Tabela 2. Modelo para cálculo do coeficiente de repetibilidade ( $r$ ) para o carāter porcentagem de ōleo dentro de cada população.

\begin{tabular}{|c|c|c|}
\hline Fontes de Variação & Q.M. & $E\left(Q . M_{.}\right)$ \\
\hline Entre as espigas & $Q_{1}$ & $\tilde{\sigma}_{\mathrm{de}}^{2}+d \tilde{\sigma}_{\mathrm{Ee}}^{2}$ \\
\hline Dentro de espigas & $Q_{2}$ & $\tilde{\sigma}_{\mathrm{de}}^{2}$ \\
\hline
\end{tabular}

onde:

$Q_{1}$ : quadrado médio entre espigas;

- $\mathrm{Q}_{2}$ : quadrado médio dentro de espigas;

$\tilde{\sigma}_{E e}^{2}$ : estimativa da esperança matemática da variāncia entre espigas;

$\tilde{\sigma}_{\text {de }}^{2}$ : estimativa da esperança matemática da variāncia dentro de es pigas;

d : nümero de determinação dentro de espigas;

$r$ : coeficiente de repetibilidade;

$h^{2}$ : herdabilidade do carāter analisado;

$\bar{\sigma}_{\mathrm{e}}^{2}$ : estimativa da esperança matemática da variāncia ambiental. 
5.4.2. Anālise reunida por população para o carāter porcentagem de ôleo

A anālise da variāncia reunida por população constitui a generalização das conclusões obtidas pelas anālises individuais, alëm de permitir a distinção entre as populações, com relação ao carāter estudado. O modelo da anālise reunida estā apresentado na Tabela 3, onde mostra também que, pelo fato dos números de espigas serem diferentes por po pulação, o coeficiente da variāncia entre populações relativo ao nümero de espigas (k) foi obtido por mëdia harmōnica entre os nümeros de espigas por população.

Tabela 3. Quadro da anālise da variāncia reunida por população, para 0 caráter porcentagem de ōleo. Considerando-se fixo o efeito de populações e aleatōrio os efeitos entre e dentro de espigas

\begin{tabular}{llc}
\hline Fontes de Variação & \multicolumn{1}{c}{ G.L. } & Q.M. \\
\hline Entre populações & $(p-1)$ & $Q_{1}$ \\
Entre espigas/populações & $\left(\left(n_{1}-1\right)+\left(n_{2}-1\right)\right)(p-1)$ & $Q_{2}$ \\
Dentro de espigas/populações & $\left(\left(n_{1}+n_{2}\right)(d-1)\right)(p-1)$ & $Q_{3}$ \\
\hline Total & $\left(\left(n_{1}+n_{2}\right) d\right)-1$ & \\
Fontes de Variação (Cont.) & $E(Q . M)$. & $F$ \\
\hline Entre populações & $\tilde{\sigma}_{\text {de }}^{2}+d \tilde{\sigma}_{\text {Ee }}^{2}+\mathrm{dk} \Sigma E_{p}^{2} /(p-1)$ & $Q_{1} / Q_{2}$ \\
Entre espigas/populações & $\tilde{\sigma}_{\text {de }}^{2}+d \tilde{\sigma}_{\text {Ee }}^{2}$ & $Q_{2} / Q_{3}$ \\
Dentro de espigas/populações & $\tilde{\sigma}_{\text {de }}^{2}$ & \\
\hline$k=2 /\left(1 / n_{1}+1 / n_{2}\right)$ & &
\end{tabular}


onde:

$n_{1}$ : número de espigas obtidas da população Original;

$n_{2}$ : número de espigas obtidas da população Alto రleo;

p : nümero de populações estudadas;

$\Sigma E_{p}^{2} /(p-1)$ : estimativa da esperança matemätica da variāncia entre populações.

0 progresso obtido foi dado pelo contraste entre as mëdias das caracteristicas estudadas nas duas populações e sua significāncia pelo teste " $t$ ", segundo as expressões:

$$
\begin{aligned}
& \bar{y}=\bar{m}_{2}-\bar{m}_{1} \\
& t=-\frac{\bar{y}}{\sqrt{s^{2}\left(1 / n_{1}+1 / n_{2}\right)}} \\
& s^{2}=\frac{S Q_{1}+s Q_{2}}{\left(n_{1}+n_{2}\right)-2}
\end{aligned}
$$

onde:

$t$ : estimativa de. " $t$ " para o contraste a ser testado, com $\left(n_{1}+n_{2}\right)-2$ graus de liberdade;

$\bar{y}$ : estimativa do contraste entre médias das populações para uma determinada caracterîstica, usada na obtenção do progresso da seleção;

$\bar{m}_{1}$ : estimativa média da caracterîstica estudada na população Origi nal;

$\bar{m}_{2}$ : estimativa média da caracterîstica estudada na população Alto oleo; 
$\mathrm{SQ}_{1}$ : soma dos quadrados para caracterīstica estudada na população Original;

$\mathrm{SQ}_{2}$ : soma dos quadrados para característica estudada na população Alto oleo;

$s^{2}$ : estimativa da variāncia média das populações para a caracterîstica envolvida pelo contraste.

Na transformação destes contrastes $(\tilde{y})$ em porcentagem tomou-se como îndice 100 a população Original. Os sinais + ou - em frente ao contraste indica se a seleção promoveu aumento (+) ou redução (-) para o carāter estudado, ou seja, o contraste representa o progresso obtido na seleção para embrião grande na caracterîstica estudada. A razão do progresso obtido pelo número de ciclos de seleção (5), dā-nos o progresso mëdio por ciclo de seleção. 
6. RESULTADOS E DISCUSSÃO

0 mês de dezembro do ano agrícola de 1978/79 apresentou uma baixa pluviosidade. Esse perīodo coincidiu com a ëpoca de florescimento das populações, nas quais pode-se notar uma redução na prolifici dade, especialmente na população Alto 0leo. Esta população apresentou, também, um pequeno aumento na duração do seu cicio atē o florescimento, em relação à população Original.

Das espigas autofecundadas de plantas das populações Original e Alto Oleo, obteve-se sementes $S_{\}}$, das quais os dados foram obtidoṣ.

6.1. Peso dos grãos

A média do peso de 100 grãos, em gramas, com o teor de umidade ao redor de $12 \%$ e, o coeficiente de variação entre espigas das populaçōes Original e Alto Oleo estão apresentados na Tabela 4. A distribuição das frequēncias relativa à caracterīstica de peso de 100 grãos, 
em ambas populações, estão representadas pela Figura 1. Os resultados mostraram que a seleção para embrião grande não proporcionou aumento sig nificativo no peso dos grãos. Contudo, obteve-se um ganho mëdio por ciclo de 0,08 grama proporcionando um ganho total nos cinco ciclos de seleção de 0,42 grama, equivalente a $1,14 \%$ em relação à população Original (Tabela 5). Embora, este ganho não seja significativo estatisticamente, mostra que a seleção praticada tendeu a aumentar o peso dos grãos.

Estes resultados indicam a possibilidade de seleção para elevar o conteüdo de óleo no milho, sem afetar negativamente o peso dos grãos, em relação à população Original. Estudos sobre tal aspecto foram realizados por ALEXANDER (1962, apud ELROUBY e PENNY, 1967), que verifi-. cou a possibilidade de se obter genótipos com alta produtividade e alto conteūdo de ôleo, tendo como base os limites fisiológicos. Contudo a maioria dos trabalihos visando aumento no teor de ōleo em milho tem mostrado um decréscimo na produtividade de grãos (WOODWORTH et alii, 1952). Isto se deve ao fato da seleçä̃o basear-se somente no conteūdo de ōleo, provocando uma redução na produção de grãos. Porēm, se a seleção basear-se, primeiramente, na produtividade de grãos e dentro das famîlias selecionar para embrião grande, torna-se possîvel a obtenção de genōtipos eficientes, tanto para produção de grãos, como para ōleo. Contudo, os resultados mostraram que neste tipo de seleção não houve redução quan to ao peso dos grãos. Resta saber se não ocorreu decréscimo na capacida de produtiva da planta. 
0 coeficiente de variação entre espigas, para peso dos grãos, mostrou que a seleção para embrião grande não alterou a variabilidade deste carāter em relação à população Original e, sim, que houve uma tendência para elevar tal variabilidade na população selecionada, indicando que este tipo de seleção não restringe a variabilidade para o peso dos grãos, proporcionando, desta forma, a possibilidade de seleção para esta caracterīstica, em programas avançados de melhoramento, jā que nesta fase, a redução da produtividade de grãos parece inevitāvel devido a limites fisiológicos (WOODWRTH et alii, 1952; LENG, 1962a).

\subsection{Volume dos grãos}

A Tabela 4, apresenta os resultados obtidos para o volume de 100 grãos e o coeficiente de variação entre espigas nas populações Original e Alto oleo. A frequência relativa deste caräter $\bar{e}$ apresentada na Figura 2. Estes resultados mostraram que a seleção para embrião grande proporcionou um aumento, embora não significativo, de $0,087 \mathrm{ml}$ por ciclo de seleção, dando um porcentual de $0,30 \%$ em relação à população Original, sendo' que o porcentual dos cinco ciclos de seleção foi de 1,52\% (Tabela 5). Esta tendência de acréscimo no volume dos grãos $\vec{e}$ explicado pelo fato de que a seleção dentro de famīlias de meios irmãos, procurou atuar sobre o aumento do embrião, e isto resultou ne'ste pequeno aumento no volume total do grão, pois os grãos que possuem embriões maiores tendem tambēm a serem maiores.

A relação porcentual entre o tamanho do grão e do embrião é dado por LENG (1967) onde mostrou que, a porcentagem do embrião no 
grão varia de 24 a $25 \%$, e que o embrião contém cerca de 87,9 a $94 \%$ do total de ōleo contido no grão, e ainda que a porcentagem de óleo no embrião varia de 51,47 a 53,72\%, mostrando a estreita relação da porcentagem de óleo com o tamanho do embrião e do grão.

0 coeficiente de variação entre progēnies para o volume do grão foi superior na população Al to óleo em relação à Original. Indicando que a seleção para embrião grande pelo fato de aumentar o conteúdo do ôleo na população Alto Oleo, esta passou a ser mais afetada pelo ambiente que a população Original, jā que o coeficiente de variação calculado estā inflacionado pela variação ambiental. Este aspecto foi discutido por JELLUM e MARION (1966) os quais mostraram que populações com maiores teores em ōleo apresentam maior interação por ambiente.

\subsection{Densidade dos grãos.}

0 carāter densidade è uma relação entre o peso e o volume. Desta forma, os resultados obtidos foram interpretados como uma relação e estão apresentados na Tabela 4, juntamente com o coeficiente de variação entre espigas. A distribuição da frequēncia relativa à densida. de dos grãos são apresentados na Figura 3. A densidade mëdia tendeu a ser maior na população Original que na Alto Őleo, indicando que a seleção para embrião grande provocou uma redução, apesar de não significativa, neste caráter. A redução total foi da ordem de $0,26 \%$ em relação a população Original (Tabela 5 ). 
Sendo a densidade uma relação entre o peso e volume, os resultados mostraram que a seleção para embrião grande apresentou uma ten dência em aumentar esses caracteres, apesar de ter proporcionado um decréscimo na densidade. Isto se deve ao fato da seleção ter sido mais eficiente no aumento do volume do grão do que no peso deste, em razăo da seleção dentro de famîlia ter se baseado no maior tamanho do embrião. Consequentemente, os grãos obtidos tenderam a um volume maior. A seleção não teve qualquer ação sobre o peso dos grãos, os quais tiveram uma tendência de aumento através de resposta correlacionada, devido a alta correlação entre o volume e o peso dos grãos.

0 coeficiente de variação entre espigas para a população Original foi superior ao da população Alto óleo. Este resultado deve tambēm ser interpretado sob forma de relação entre peso e volume. No pe so dos grãos, o coeficiente de variação se manteve praticamente constante em ambas as populações. No volume dos grãos, o coeficiente de variação da população Alto Oleo foi superior ao da população Original. Desta forma, uma redução do coeficiente de variação da população Alto Oleo para o caráter densidade dos grãos deve-se ao fato de ter ocorrido um aumento deste parâmetro no caräter volume dos grãos.

\subsection{Conteüdo de ōreo}

A Tabela 4 apresenta a média, o coeficiente de variaçăo entre espigas e o coeficiente de repetibilidade do carāter porcentágemde óleo nas populações Original e Alto oleo. O progresso obtido, total e 
por ciclo de seleção, na população Alto Ōleo em porcentagem relativo à população Original estão apresentados na Tabela 5. As anălises da variāncia referentes às determinações de porcentagem de öleo para as populações Original e Alto Olleo são apresentadas nas Tabelas 6 e 7, respecti vamente. A Tabela 8 apresenta a anālise da variância reunida por populações, as quais diferiram significativamente entre si pelo teste "F" "pa ra o carāter estudado. Isto demonstra a eficiência do mëtodo de seleção empregado para elevar o conteúdo de ōleo nos grãos de milho.

A seleção entre famîlias de meios irmãos para produtividade, e dentro das famîlias para embrião grande, proporcionou um aumento na porcentagem de ôleo de $1,44 \%$ por ciclo em relação à população Original. Este aumento equivale, em valores absolutos a 0,08\%. 0 aumento porcentual dos cinco ciclos, em relação à população Original foi de $7,18 \%$, estatisticamente significativo ao nivel de $1 \%$ de probabilidade. ELROUBY e PENNY (1967) encontraram, em valores absolutos, por ciclo : de seleção, ganhos de 0,$53 ; 0,39$ e $0,50 \%$, respectivamente, para seleção massal, seleção entre famîlias de irmãos gemanos e seleção recorrente. Da mesma forma, WOODWORTH et alii (1952) haviam detectado um ganho médio de $2,75 \%$ em relação à população Original, nas cinco primeiras gerações de seleção para alto óleo, aplicando o método espiga-por-fileira.

Embora a metodologia utilizada no presente trabalho não tenha possibilitado estimar a variabilidade genética do carāter estudado, LENG (1962a) refere que esta variabilidade pode ser também medida pelo coeficiente de variação, embora este parāmetro contenha parte da 
variação ambiental. Os coeficientes de variação estimados para o carâter porcentagem de öleo mostraram a presença de variabilidade entre espigas para esta característica nas populaçōes Original e Alto oleo. Esta variabilidade tende a ser mais acentuada na população Original. Fato semelhante e ainda mais acentuado, ocorreu com a variação dentro das espigas, como pode ser observado pelo coeficiente de variação dentro de espiga. Os vaiores obtidos para variaçäo entre espigas se aproxima dos ob tidos por LENG (1962a), onde o coeficiente de variação em 13 gerações de seleção para alto ôleo variou de 5,4\% a 14,6\%. O fato da população Original ter apresentado maior variabilidade, de acordo com seu coeficiente de variação, tanto entre como dentro das espigas, se deve à constatação de que a seleção tende a diminuir a variabilidade no decorrer dos ciclos, nos caracteres selecionados. Isto e mostrado no trabalho de LIMA (1977) onde a seleçã, entre e dentro de famỉitias de meios imãos para produtividade de grãos, acarretou uma redução de 7,35 para $6,26 \%$ no coeficiente de variação genética, em três ciclos de seleção. A redução da variabilidade para o caräter porcentagem de öleo na população Alto óleo, em relação a população Original é tambëm observada na Figura 4, a qual mostra a distribuição das frequéncias relativas ao teor de ōleo nestas populações. A constatação de variabilidade, estatisticamente significativa, na população Alto oleo indica a possibilidade de novos progressos com a continuidade de seleção para elevar o conteúdo de óleo nessa população.

Os resultados obtidos no presente trabalho mostraram que, embora a seleção entre famîlia tenha sido realizada com base na 
produtividade de grãos, o aumento no conteūdo de ôleo foi devido a seleção praticada dentro das famîlias para embrião grande. Esse aumento foi bastante significativo, sendo comparāveis aos trabalhos onde se apli cou seleção visando somente a elevação do conteủdo de óleo. Isto se deve ao fato do tipo de seleção ter explorado a variância genética aditiva disponivel dentro de famîlias de meios irmãos para o carăter tananho do embrião e a elevada relação existente entre o tamanho do embrião e o con teüdo de ôleo no grão de mitho.

0 coeficiente de repetibilidade para o carāter porcentagem de óTeo foi superior na população Alto OTleo, concordando com os resultados obtidos por HOPKINS (1899), GENTER et alii (1956), JELLUM e MARION (1966), os quais mostraram que populaçōes com maior teor em óleo estão sujeitas a uma maior interação por ambiente. Estes valores do coe ficiente de repetibilidade, são comparāveis com os valores da herdabilidade obtidos por DUDLEY e LAMBERT (1969) e MIRANDA et alii (1976), os quais foram da ordem de 12,5 e $15,7 \%$, respectivamente. Pois, o coeficiente de repetibilidade representa o limite mäximo da herdabilidade, jā que este contém parte da variação ambiental.

\subsection{Estudos de correlação}

Os coeficientes de correlação fenotipica obtidos estão apresentados na Tabela 9 para as populações estudadas. A correlação entre peso e volume dos grãos foi altamente significativa e positiva para as duas populações, indicando que um maior volume de grãos está 
relacionado com o aumento de seu peso. Quanto ao peso e densidade, na população Original, não se detectou significância, embora houvesse uma tendência de ser positiva. Contudo, na população Alto ōleo apresentou uma correlação estatisticamente significativa e negativa, indicando que um maior peso contribui para reduzir a densidade dos grãos, fato este ex plicado por ser a densidade uma relação entre peso e volume. A seleção dentro das famililias para embrião grande provocou aumento tanto no peso como no volume dos grãos, sendo este aumento ma is acentuado no volume, conforme discutido anteriormente.

A correlação entre o peso dos grãos e a porcentagem de óleo em ambas as populações não apresentou significância estatîstica. To davia, observa-se uma tendência desta ser positiva na população Original e negativa na população Alto ōleo. As correlações obtidas na população Original estão de acordo com os dados citados por ARNOLD e BAUMAN (1976) e ARNOLD et alii. (1974).

A falta de correlação para pẹso de grãos e porcentagem de óleo pode ser explicada segundo os resultados obtidos por ALEXANDER e LAMBERT (1968), os quais verificaram que o conteūdo de ōleo e produção de calorias por planta deve-se provavelmente a efeitos independentes. Os autores sugerem que a capacidade das plantas em produzir carboidratos e sintetizar ōleo é fisiologicamente independente. Existindo, desta forma, a possibilidade de se obter genótipos com altas produtividades de carboidratos e, simultaneamente, elevado conteúdo de óleo. 
As correlações entre o volume com a densidade e a porcentagem de ōleo dos grãos na população Original não foram estatisticamente significativa. Resultados semelhantes foram obtidos por ARNOLD e BAUMAN (1976) e por ARNOLD et alii (1974). Entretanto, para a populäção A.l to Oleo obteve-se significancia negativa para correlação entre volume e den sidade, mostrando, desta forma, que embora estas duas características não estivessem correlacionadas entre si na população Original, quando se prá tica seleção para aumentar o tamanho do embrião, provoca-se um aumento no volume dos grãos, fazendo com que a densidade tenha uma dependéncia negativa com este carāter, embora a seleção tenha também aumentado o peso dos grãos.

Embora não tenha sido encontrado correlação significativa entre a porcentagem de ōleo e volume de grãos, houve uma tendéncia desta ser positiva na população Original, e negativa na popülação Alto oleo.

A densidade dos grãos não apresentou correlação significativa com a porcentagem de ôleo, em ambas populações. Contudo, apresentou uma tendēncia para ser negativa na população Original e positiva na. população Al to oleo. 
7. CONCLUSOOES

Os resultados obtidos no presente trabalho, permitiram chegar às seguintes conclusões:

1. A seleção massal praticada dentro das famîlias de meios irmãos para embrião grande proporcionou um aumento de 7,18\% na população Alto 0َleo, em relação a população Original para o conteüdo de öleo nos grãos de milho.

2. 0 tipo de seleção empregado não conduziu a alterações significativas nas caracterîsticas de peso, volume e densidade dos grãos. Contudo, houve uma tendēncia em elevar o peso e volume e de reduzir a densidade dos grãos na população Alto oleo em relação a população Original.

3. A população com teor de óteo mais elevado, visualmente, mostrou ser mais sensivel em suas caracteristicas vegetativas à variação ambiental do que a população com menor teor de óseo. 
4. 0 mëtodo de seleção empregado proporcionou que as correlações entre porcentagem de ōleo e as características de peso, volume e densidade dos grãos se mantivessem como na população Original.

5. 0 carāter densidade dos grãos, por ser uma relação entre o peso e o volume, apresenta restrições de interpretações para ser usado como parāmetro de seleção. 
8. SUMMARY

In order to get mayze corn genotyps with a higher yelding and oil content, the population ESALQ-VD-2 was submited to a selection procedure using half sib families. Selection among families were done mainly for yielding, and within only to increase the kernel germ size, since the oil content is highly correlated with it.

The mainly goal of this research was to evaluated the selection procedure applied, and see if the oil content of the kernel increased after five cycles of selection. To avoid any pollen effect, data for 100 kernel weight, volume and density were obtained from the $\mathrm{s}_{1}$ kernels.

Comparison between the Original and High 0il population were done. A total of ninety six $S_{1}$ ears from the Original population and forty three from the selected population were analysed.

Based on the data analyses was concluded that the selection procedure applied over the Original population was efficient and that a 
progress of $1.44 \%$ per cycle was achieved.

The results obtained for 100 kernel weight, volume and density in the High $0 i l$ population remaining about the same as in the Original population.

Environmental effects over the vegetative characteristics were detected mostly for the High $0 i 1$ population.

Statisticaly no correlation was detected between the oil content and 100 kernel weight, volume and density in both populations. 


\section{LITERATURA CITADA}

ALEXANDER, D.E., 1962. Corn as an oil crop. Proceeding of the $17^{\text {th }}$ Annual Hybryd Corn Industry - Research Conference, 17:85-91. (Original não consultado; apud ELROUBY, M.M. e L.H.PENNY, 1967. Variation and covariation in high oil population of corn (Zea mays L.) and their implications in selection. Crop Science, Madison, $\underline{7}(3): 216-219)$.

ALEXANDER, D.E., L.S ILVELA, F.I. COLLINS e R.C. RODGERS, 1967. Analys is of oil content of maize by wide line NMR. Journal American 0il Chemists Society, Illinois, 44(9):555-558.

ALEXANDER, D.E. e R.J. LAMBERT, 1968. Relationship of kernel oil content to yield in maize. Crop Science, Madison, $\underline{8}(3): 273-274$.

ALEXANDER, D.E., J.W. DUDLEY e R.G. GREECH, 1970. Corn breeding and genetics. In: INGLETT, G.E. Ed. Corn: culture, processing, products. The Avi. Pub.' Comp., Inc. p.6-23. 
ALLARD, R.W., 1971. Principios do melhoramento genëtico das plantas. São Paulo, Editora Edgard Blucher Ltda. $381 p$.

ARNOLD, J.M., L.M. JOSEPHSON, W.L. PARKS E H.C. KINCER, 1974. Influence of nitrogen, phosphorus, and potassium applications on stalk quality caracteristics and yield of corn. Agronomy Journal, Madison, 66(5): 605-608.

ARNOLD, J.M. e L.F. BAUMAN, 1976. Inheritance of and interrelationship among maize kernel traits and elemental contents. Crop Science, Madison, $\underline{16}(3): 439-440$.

BAUMAN, L.F., T.F. CONWAY e S.A. WATSON, 1963. Heritability of variations in oil content of individual corn kernels. Science, New York, 139 (3554): 498-499.

BAUMAN, L.F., T.F. CONWAY E S.A. WATSON, 1965. Inheritance of variations in oil content of individual corn (Zea mays L.) kernels. Crop Science, -Madison, $\underline{5}(2): 137-138$.

BEADLE, J.B., D.E. JUST, R.E. MORGAN e R.A. REINERS, 1965. Composition of corn oil. Journal American 0il Chemists Society, Illinois, 42 (1): 90-95. 
BISCEGLI, C.I., 1977. Construção de um espectrômetro de ressonância mag nética nuclear (RMN) de banda larga. Duas aplicações tecnológicas dessa técnica. São Carlos, IFQSC/USP. 62p. (Dissertação de Mestrado).

BRUNSON, A.M., F.R. EARLE e J.J. CURTIS, 1948. Interrelations among factors influencing the oil content of corn. Journal American Society. Agronomy, Geneva, 40(2):180-185.

CONWAY, T.F. e F.R. EARLE, 1963. Nuclear magnetic resonance for determining oil content of seeds. Journal American 0il Chemists Society, Illinois, $40(2): 265-268$.

CURTIS, J.J., A.M. BRUNSON, J.E. HUBBARD e F.R. EARLE, 1956. Effect of the pollen parent on oil content of corn kernel. Agronomy Journal, Madison, $48(12): 557-555$.

CURTIS, P.E., E.R. LENG e R.H. HAGEMAN, 1968. Developmental changes in - oil and fatty acid content of maize strains varying in oil content. Crop Science, Madison, $\underline{8}(6): 689-693$.

DUDLEY, J.W. e R.J. LAMBERT, 1959. Genetic variability after 65 generations of selection in 111 inois oil and protein strains of Zea mays. L. In: DUDLEY, J.W. Ed., 1974. Seventy Generations of selections for oil and protein in maize. Crop Science Society of America, Inc. Madison, Wisconsin. p.175-180. 
DUDLEY, J.W., R.J. LAMBERT E D.E. ALEXANDER, 1974. Seventy Generations of selection for oil and protein concentration in the maize kernel. In: DUDLEY, J.W. Ed., 1974. Seventy generations of selection for oil and protein in maize. Crop Science Society of America, Inc. Madison, Wisconsin, p.181-211.

DUDLEY, J.W., R.J. LAMBERT e I.A. de 1a ROCHE, 1977. Genetic analysis of crosses among corn strains divergently selected for percent oil and protein. Crop Science, Madison, 17(1):111-117.

ELROUBY, M.M. e L.H. PENNY, 1967. Variation and covariation in high oil population of corn (Zea mays L.) and their implications in selection. Crop Science, Madison, $7(3): 216-219$.

GARWOOD, D.L., E.J. WEBER, R.J. LAMBERT E D.E. ALEXANDER, 1970. Effect of different cytoplasms on $0 i 1$, fatty acids, plant height, and ear height in maize (Zea mays L.). Crop Science, Madison, 10(1):39-41.

GENTER, C.F., J.F. EHEART e W.N. LINKOUS, 1956. Effects of 1ocation, hybrid, fertilizer, and rate of planting on the oil and protein contents of corn grain. Agronomy Journal, Madison, 48(1):63-67.

GLOVER, D.V. e G.A. TOSELLO, 1973. Kernel characteristics,protein quality and biological value of the sugary -2 mutation and its combination with opaque -2 in Zea mays L.. Agronomy Abstracts, $65^{\text {th }}$ Annual Meeting, Madison, p.5. (Abst.). 
1OPKINS, C.G., 1899. Improvement in the chemical composition of the corn kernel. In: DUDLEY, J.W.Ed., 197A. Seventy generations of selection. for oil and protein in maize. Crop Science Society of America, Inc. Madison, Wisconsin. p.7-29.

HOPKINS, C.G., L.H. SMITH E E.M. EAST, 1903. The structure of the corn kernel and the composition of its different parts. In: DUDLEY, J.W. Ed., 1974. Seventy generations of selection for $0 i 1$ and protein in. maize. Crop Science Society of America, Inc. Madison, Wisconsin. p. 33-63.

JELLUM, M.D. e J.E. MARION, 1966. Factors affeting oil content and oil composition of corn (.Zea mays L.) grain. Crop Science, Madison, 6 $(1): 41-42$.

JELLUM, M.D., 1967. Fatty açid composition of corn (Zea mays L.) oil as influenced by kernel position on ear. Crop Science, Madison, ㄱ(6): $593-595$.

JELLUM, M.D., 1970. Developmental changes in fatty acid composition of oil in kernel fractions of corn (Zea mays L.). Journal American 0 il Chemists Societs, I11inois, 47(3):245-248.

KINOSHITA, K. e E. PATERNIANI, 1974a. Seleção para alto teor de óleo no mitho Centralmex. Relatório Cientîfico do Instituto de Genëtica, Piracicaba, 7:62-67. 
KINOSHITA, K. e E. PATERNIANI, 1974b. Proporção endosperma/embrião e o seu efeito sobre o teor de öleo no milho Centralmex. Relatório Cientifico do Instituto de Genética, Piracicaba, 7:68-73.

LAMBERT, R.J., D.E. ALEXANDER E R.C. RODGERS, 1967. Effect of kernel position on oil content in corn (Zea mays L.). Crop Science, Madison, 7(2): $143-144$.

LENG, E.R., 1961. Predicted and actual responses during long - term selection for chemical composition in maize. Euphytica, Wageningen, $10(3): 368-378$.

LENG, E.R., 196?a. Results of long - term selection for chemical composition in maize and their significance in evaluating breeding systems. In: DUDLEY, J.W. Ed., 1974. Seventy generations of selection for oil. and protein in maize. Crop Science Society of America, Inc. Madison, Wisconsin, p.749-172.

LENG, E.R., 1962b. Selection reversal in strains of corn previously long - term selected for chemical composition. Crop Science, Madison, $2(2): 167-170$.

LENG, E.R., 1967. Changes in weight, germ ratio, and oil content during kernel development in high oil corn (Zea mays L.). Crop Science, Madison, $\underline{7}(4): 333-334$. 
l.IMA, M., 1977. Seleção entre e dentro de famîlias de meios irmãos nà população de milho ESALQ-VD-2. Piracicaba, SP. ESALQ/USP. 71p. (Dis sertação de Mestrado).

LONNQUIST, J.H., 1964. A modification of the ear-to-row procedure for the improvement of maize populations. Crop Science, Madison, $\underline{4}(2)$ : 227-228.

MILLER, P.A. e B. BRIMHALL, 1951. Factors influencing the oil and protein content of corn grain. Agronomy Journal, Madison, 43(7):305311.

MIRANDA, P., R. RUSCHEL e E. PATERNIANI, 1976. Avaliação de famîlias de meios irmãos no mitho (Zea mays L.) Centralmex, para produção de grãos e ōleo. Boletim Técnico Instituto Pesquisas Agronōmicas, Recife, 76: 37 p..

MORENO - GONZALEZ, J., J.W. DUDLEY e R.J. LAMBERT, 1975. A design III - study of linkage disequilibrium for percent oil in maize. Crop Science, Madison, $15(6): 840-843$.

N.I.L., 1972. Newport Instruments Limited. Use of the Newport Quantity Analyzer. Newport Pagnel1, Buckinghamshire, England, 40p.

PATERNIANI, E., 1968. Formação de compostos de milho. Relatōrio Cientīfico do Instituto de Genética, Piracicaba, 2:102-108. 
PATERNIANI, E., 1972. Relação entre tamanho relativo do embrião do "miTho avaliado visualmente e o teor de óleo. Relatório Científico do Instituto de Genética, Piracicaba, 6:86-90.

PATERNIANI, E., J.R. ZINSLY e J.B. MIRANDA FILHO, 1977. Populações meThoradas de milho obtidas pelo Instituto de Genética. Relatōrio Cientîfico do Instituto de Genética, Piracicaba, 11:108-114.

PONELEIT, C.G. e D.E. ALEXANDER, 1965. Inheritance of linoleic and oleic acids in maize. Science, New York, 147(3665):1585-1586.

PONELEIT, C.G. e L.F. BAUMAN, 1970. Diallel analyses of fatty acids in corn (Zea mays L.) oil. Crop Science, Madison, 10(4):338-341.

QUEIROZ, M.A., 1969. Correlações genēticas e fenotīpicas em progēnies de meios irmãos de mitho (Zea mays L.) e suas implicações com o melho ramento. Piracicaba, SP.ESALQ/USP. 71p. (Dissertação de Mestrado).

ROCHE, I.A. de 1a, D.E. ALEXANDER e E.J. WEBER, 1971. Inheritance of oleic and linoleic acids in Zea mays L.. Crop Science, Madison, 11 $(6): 856-859$.

RUSCHEL, R., 1972. Selection for oil and relationships among oil, protein and lysine in an opaque -2 populations of maize (Zea mays L.), Purdue University, USA. (PhD Thesis). 
RUSCHEL, R., 1975. Correlações entre ōleo, proteina e lisina em milho opaco-2. Pesquisa Agropecuāria Brasileira - Série Agronomia, Rio de Janeiro, $10(11): 7-9$.

RUSKOVA, K., 1974. The effect of the direction of the cross on oil, protein and lysine content in the grain of maize. Genetika i Selektsiyc, Knezha, ㄱ( $(5): 353-360$. In: Plant Breeding Abstracts, 1975. 45(7):5368. (Abst.)

SPRAGUE, G.F. e B. BRIMHALL, 1949. Quantitative inheritance of oil in the corn kernel. Agronomy Journal, Madison, 41(1):30-33.

SPRAGUE, G.F. e B. BRIMHALL, 1950. Relative effectiveness of two systems of selection for oil content of the corn kernel. Agronomy Journal, Ma dison, $42(2): 83-88$.

SPRAGUE, G.F., P.A. MILLER e B. BRIMHALL, 1952. Additional studies of the relative effectiveness of two systems of selection for oil content of corn kernel. Agronomy Journal, Madison, 44(6):329-331.

STEEL, R.G.D. e J.H. TORRIE, 1960. Principles and procedures of statistics. With special reference to the biological sciences. McGraw-Hill Book Company, Inc. New York, USA. 481p.

VENCOVSKY, R., 1977. Princīpios de genética quantitativa. Publicação didática do Departamento de Genética, Piracicaba, 16:47-56. 
WEBER, E.J. e D.E. ALEXANDER, 1975. Breeding for lipid composition in corn. Journal American 0il Chemists Society. Illinois, 52(4):370-373.

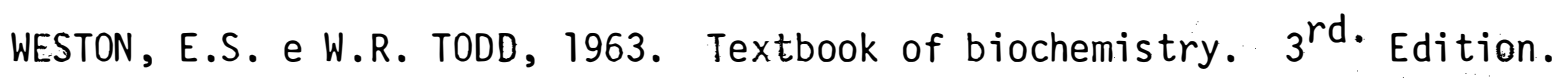
The MacMillan Co., New York, 1423p. COriginal não consultado; apúd ALEXANDER, D.E. e R.J. LAMBERT, 1968. Relationship of kernel oil. content to yield in maize. Crop Science, Madison, 8(3):273-274).

WOODWORTH, C.M. e W.J. MUMM, 1936. New records set in altering composition

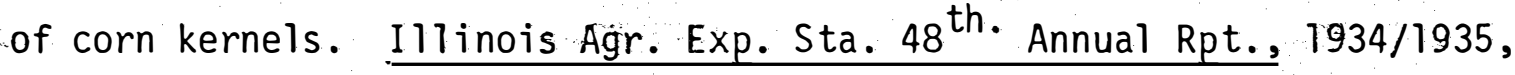
p.47-50. (Original não consultado; apud MILLER, P.A. e B. BRIMHALL, 1951. Factors influencing the oil and protein content of corn grain. Agronomy Journal, Madison, $\underline{43}(7): 305-311)$.

WOODWQRTH, C.M., E.R. LENG e R.W. JUNGENHEIMER, 1952. Fity generations of selection for protein and oil in corn. In: DUDLEY, J.W. Ed.,1974. Seventy generations of selection for oil and protein in maize. Crop Science Society of America, Inc. Madison, Wisconsin. p.121-131.

ZUBER, M.S., 1942. Relative efficiency of incomplete block designs using corn uniformity trial data. Agronomy Journal, Madison, 34 (1):30-47. 
TABELAS DE RESULTADOS 


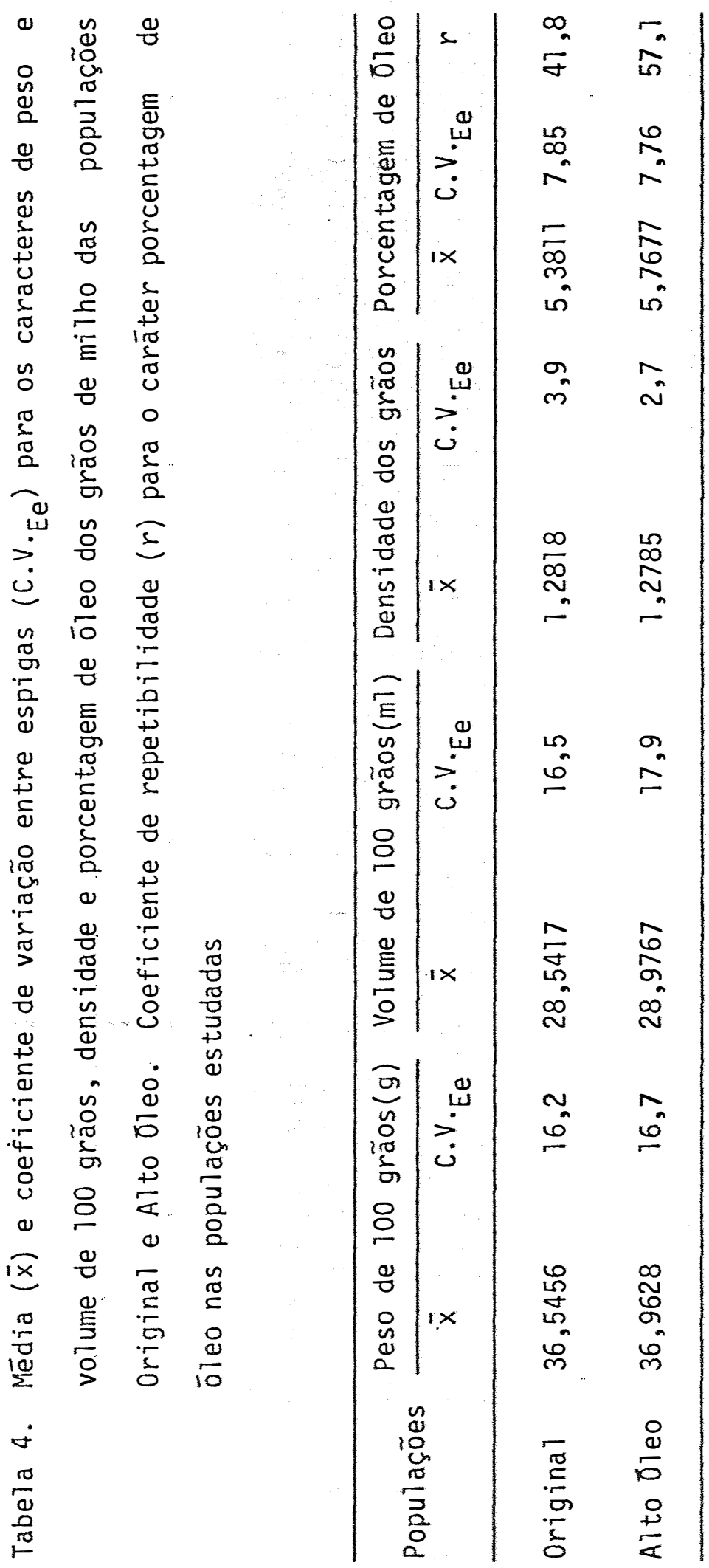


Tabela 5. Progressos obtidos pela seleção dentro de famîlias de meios irmãos para embrião grande nos caracteres de peso e volume de 100 grãos, densidade e porcentagem de ōleo dos grãos

\begin{tabular}{lcc}
\hline Caracteres & $\begin{array}{c}\Delta G / \text { ciclo } \\
\%\end{array}$ & $\begin{array}{c}\Delta G / \text { Total } \\
\% \text { (5 ciclos })\end{array}$ \\
\hline Peso de 100 grãos & 0,23 & $1,14 \mathrm{~ns}$ \\
Volume de 100 grãos & 0,30 & $1,52 \mathrm{~ns}$ \\
Densidade dos grãos & $-0,05$ & $-0,26 \mathrm{~ns}$ \\
Porcentagem de ōleo & 1,44 & $7,18 * \star$ \\
\hline
\end{tabular}

ns : não significativo pelo teste " $t$ "

** : significativo pelo teste " $t "(P=1 \%)$

Tabela 6. Anālise da variāncia para porcentagem de ōleo, relativa as de términações realizadas entre e dentro de espigas $S_{1}$ da população Original

\begin{tabular}{lcccc}
\hline Fontes de Variação & G.L. & Q.M. & C.V.(\%) & E(Q.M.) \\
\hline Entre espigas & 95 & $0,6045^{\star \star}$ & 7,85 & $\bar{\sigma}^{2}+2 \bar{\sigma}^{2}$ \\
& & & $\ddots$ & de Ee \\
Dentro de espigas & 96 & 0,2479 & 9,25 & $\bar{\sigma}_{\text {de }}^{2}$ \\
\hline
\end{tabular}

Total

191

** significativo pelo teste " $F "(P=1 \%)$ 
Tabela 7. Análise da variāncia para porcentagem de óleo, relativa as determinações realizadas entre e dentro de espigas $S_{1}$ da população Al to oleo

\begin{tabular}{lcccc}
\hline Fontes de Variação & G.L. & Q.M. & C.V.(\%) & E(Q.M.) \\
\hline Entre espigas & 42 & $0,5516^{* *}$ & 7,76 & $\bar{\sigma}_{\text {de }}^{2}+2 \bar{\sigma}_{\text {Ee }}^{2}$ \\
Dentro de espigas & 43 & 0,7507 & 6,73 & $\bar{\sigma}_{\text {de }}^{2}$ \\
\hline Total & 85 & & & \\
\hline
\end{tabular}

** significativo pelo teste "F" $(P=1 \%)$ 


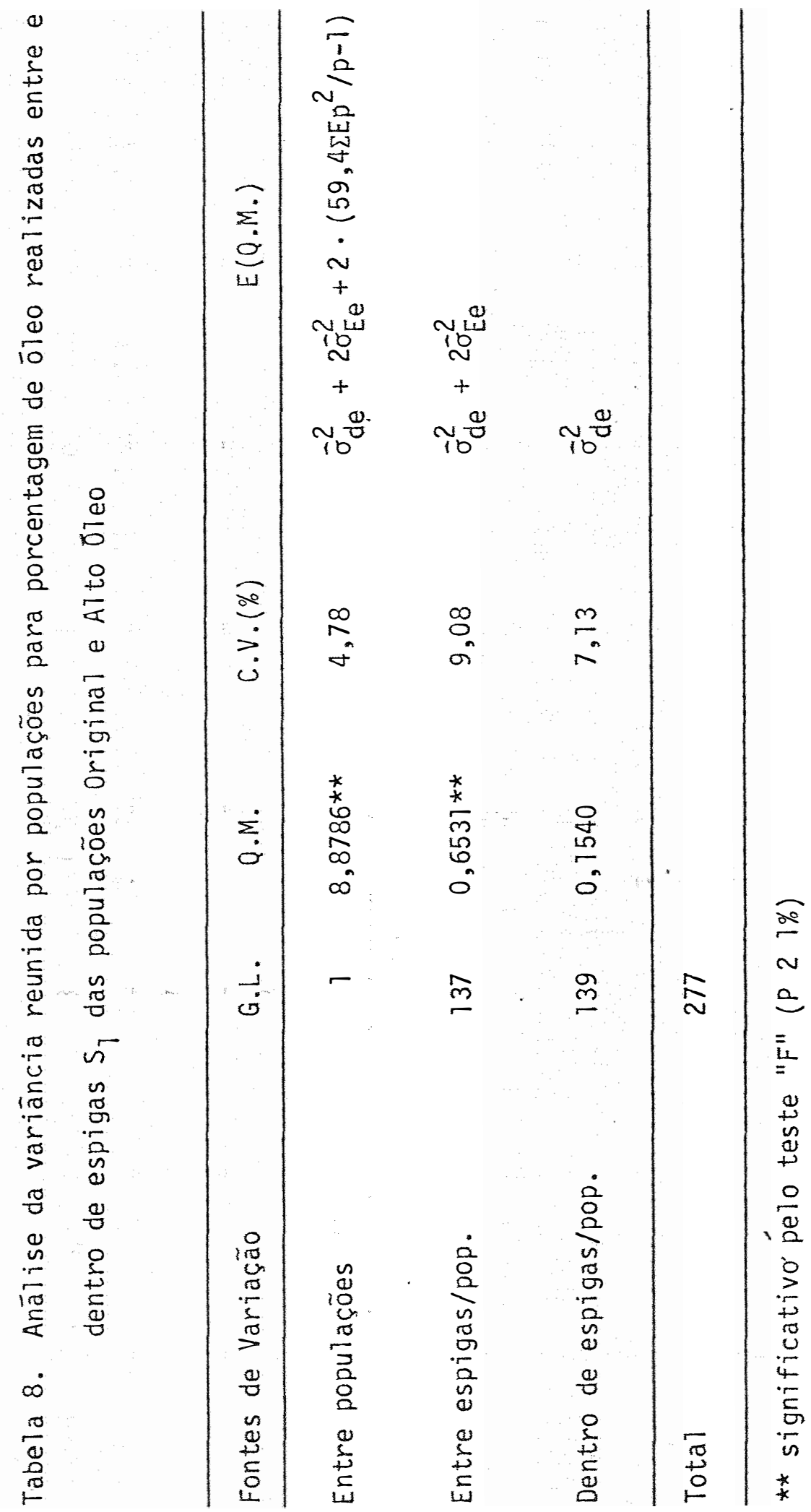




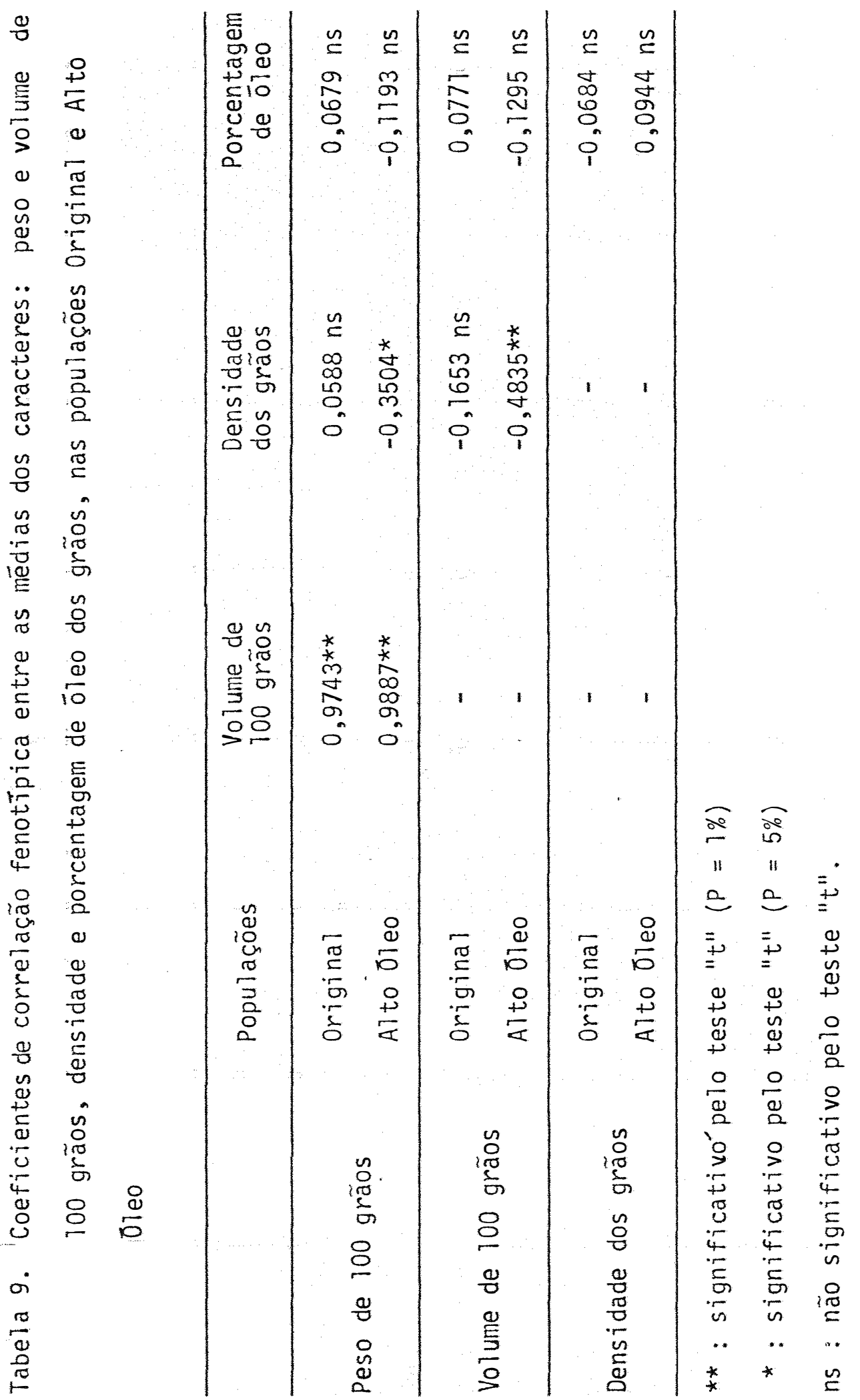




\section{FIGURAS}




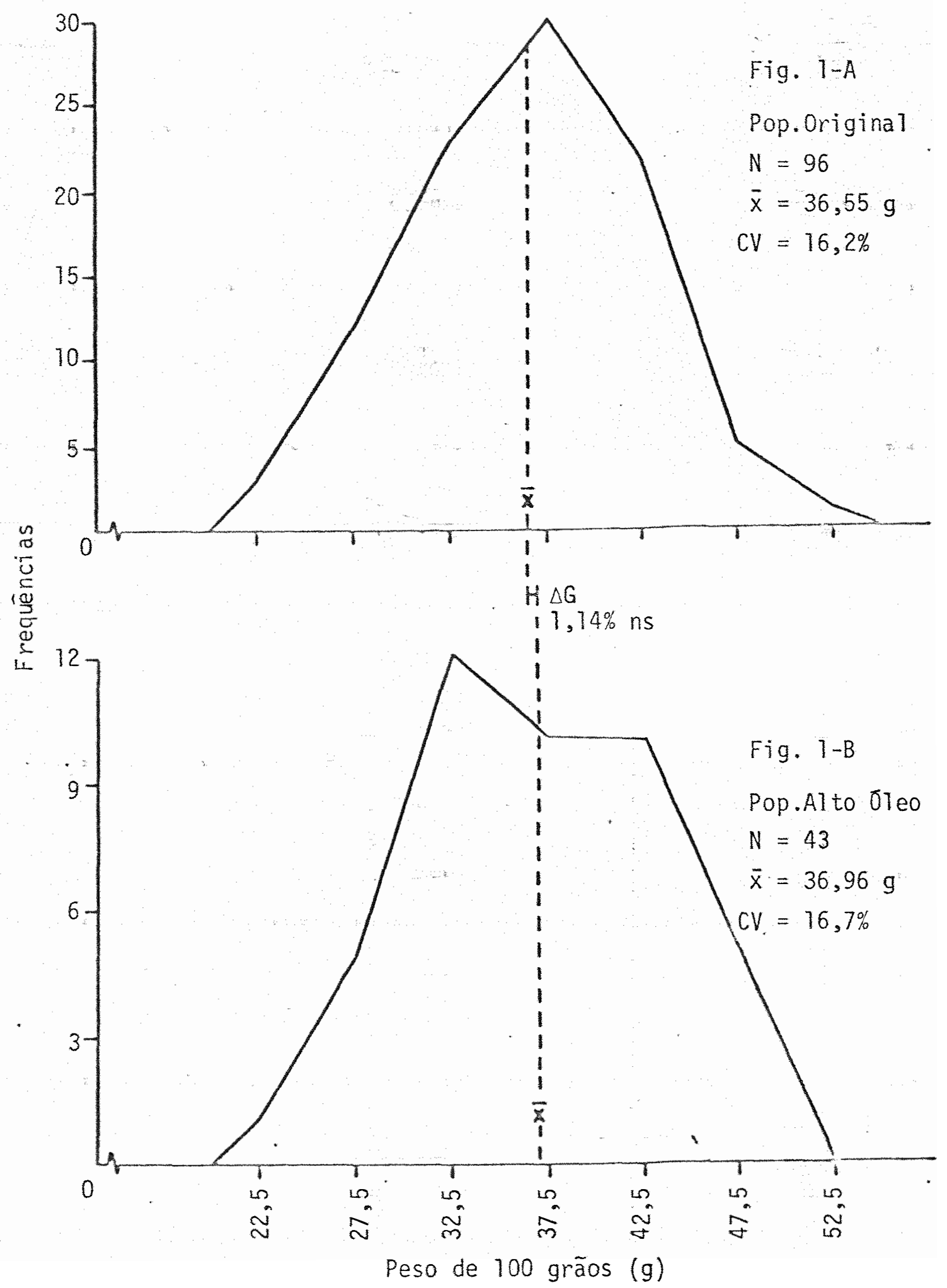

Figura 1. Distribuição das frequencias relativas ao peso de 100 grãos das sementes $S_{1}$ do Composto ESALQ-VD-2 


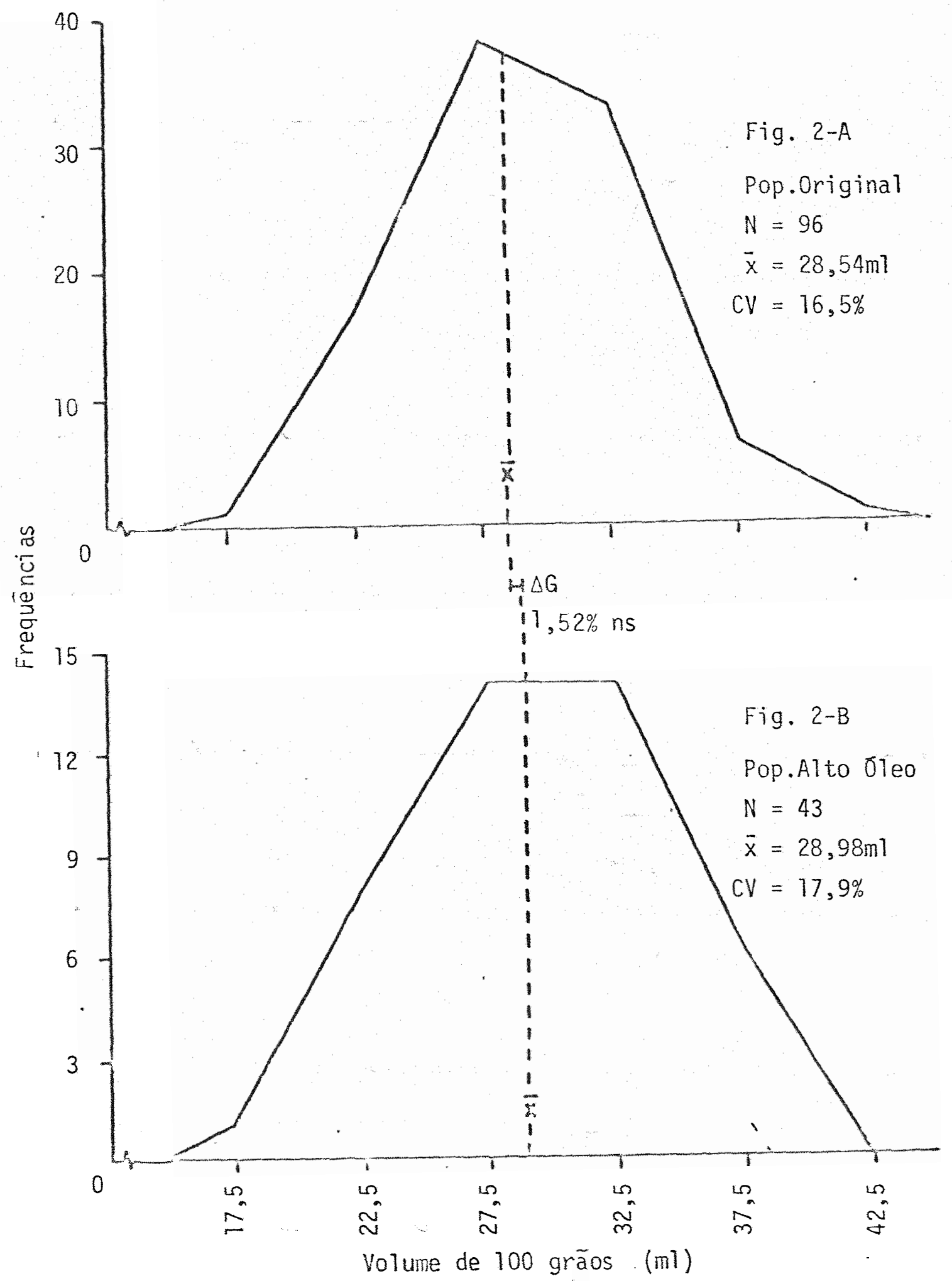

Figura 2. Distribuição das frequencias relativas ao volume de 100 grãos das sementes $S_{1}$ do Composto ESALQ-VD-2 


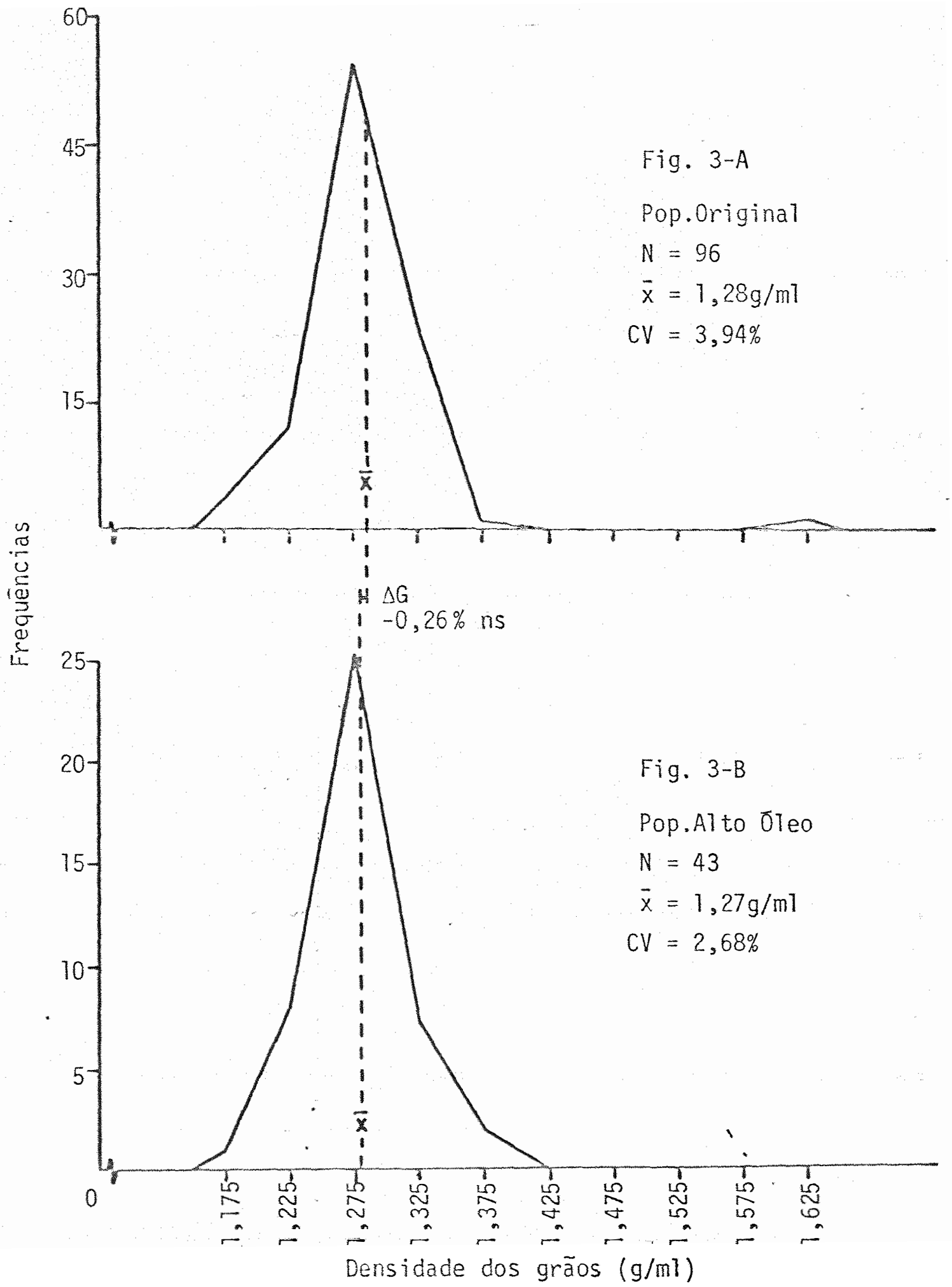

Figura 3. Distribuição das frequências relativas a Densidade das sementes $S_{1}$ do Composto ESALQ-VD-2 


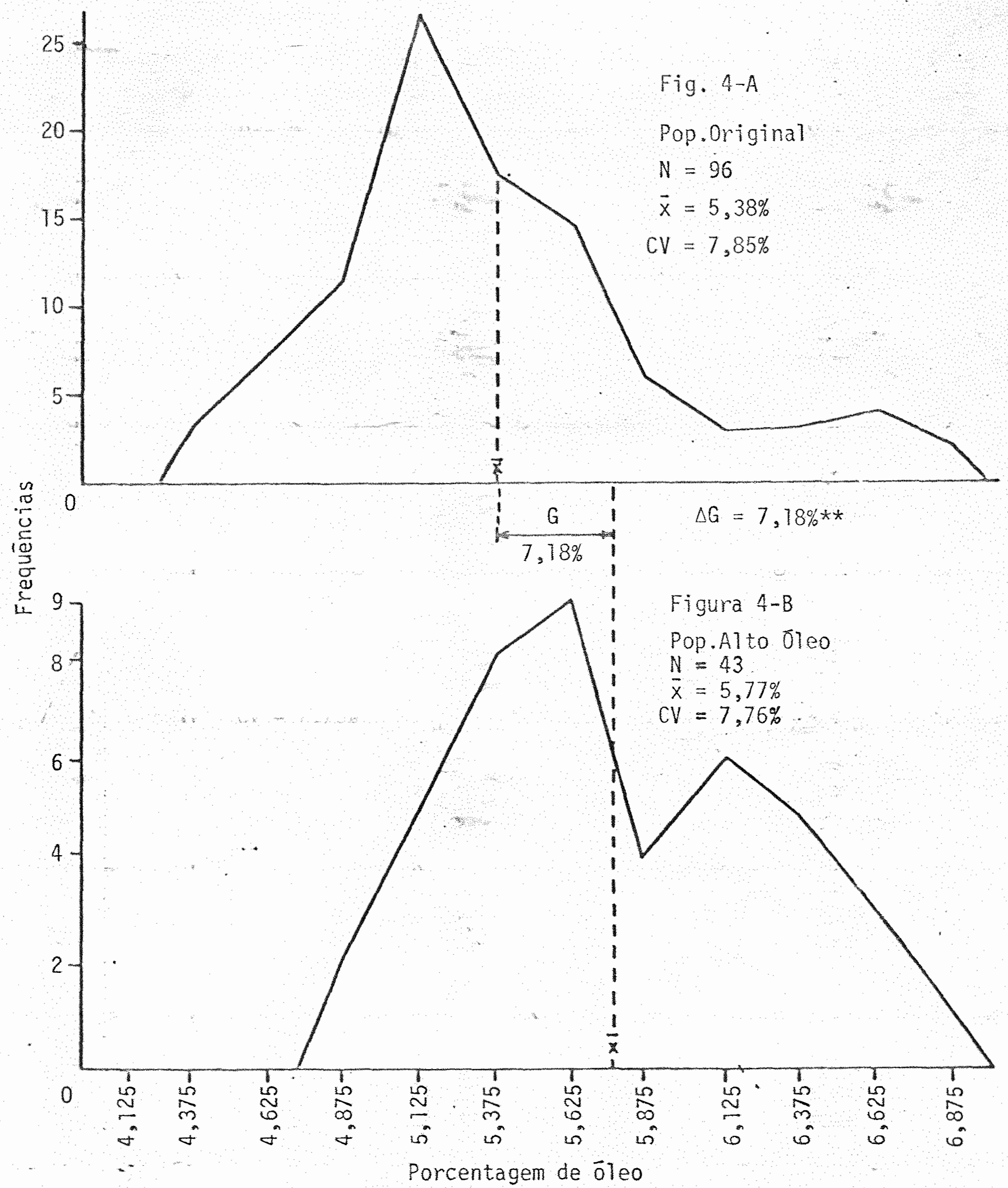

Figura 4. Distribuição das frequenciàs relativas à porcentagem de óleo das espigas $S_{1}$ do Composto ESALQ-VD-2 